

\title{
II. BREXIT Y GIBRALTAR. TRATADO DE RETIRADA, PROTOCOLO, TRATADO FISCAL Y MOUS (2018-2020)
}

\author{
Inmaculada GONZÁLEZ GARCÍA*; Alejandro DEL VALLE GÁLVEZ; \\ Lorena CALVO MARISCAL; Juan Domingo TORREJÓN RODRÍGUEZ
}

\section{Documentación incluida en este apartado:}

DOCUMENTO 1. Acuerdo sobre la retirada del Reino Unido de Gran Bretaña e Irlanda del Norte de la Unión Europea y de la Comunidad Europea de la Energía Atómica, DOUE L 29, 31.1.2020. Se han seleccionado: Preámbulo; Primera Parte, Disposiciones comunes; Sexta Parte, Disposiciones institucionales y finales: Título II, Disposiciones Institucionales (solo art. 165) y Título IV, Disposiciones finales.

DOCUMENTO 2. Agreement on the withdrawal of the United Kingdom of Great Britain and Northern Ireland from the European Union and the European Atomic Energy Community, OJEU L 29, 31.1.2020. Selection: Preamble; Part One, Common provisions; Part Six, Institutional and final provisions: Title II, Institutional provisions (art. 165 only) and Title IV, Final provisions.

DOCUMENTO 3. Protocolo sobre Gibraltar. Acuerdo sobre la retirada del Reino Unido de Gran Bretaña e Irlanda del Norte de la Unión Europea y de la Comunidad Europea de la Energía Atómica, DOUE L 29, 31.1.2020.

DOCUMENTO 4. Protocol on Gibraltar. Agreement on the withdrawal of the United Kingdom of Great Britain and Northern Ireland from the European Union and the European Atomic Energy Community, OJEU L 29, 31.1.2020.

\footnotetext{
* Esta Sección se enmarca en el Proyecto de Investigación financiado por la Fundación Pública Andaluza Centro de Estudios Andaluces (PRY205/19): "La incidencia del 'Brexit' en la cooperación transfronteriza entre Gibraltar-Campo de Gibraltar y Andalucía”, coordinado por la Profesora Inmaculada González García. Período de vigencia, 2020-2022.
} 
DOCUMENTO 5. Autorización de Tratados y Convenios Internacionales. Acuerdo Internacional en materia de fiscalidad y protección de los intereses financieros entre el Reino de España y el Reino Unido de la Gran Bretaña e Irlanda del Norte en relación con Gibraltar, hecho «ad referendum» en Madrid y Londres el 4 de marzo de 2019, BOCG núm. 7, 14 de febrero de 2020.

DOCUMENTO 6. International Agreement on Taxation and the Protection of Financial Interests Between the United Kingdom of Great Britain and Northern Ireland and the Kingdom of Spain regarding Gibraltar, London and Madrid, 4 March 2019. Foreign and Commonwealth Office, 15 March 2019.

DOCUMENTO 7. Memorando de Entendimiento entre el Reino de España y el Reino Unido el 29 de noviembre de 2018, sobre cooperación policial y aduanera. Memorandum of Understanding on cooperation in police and customs matters.

DOCUMENTO 8. Memorando de Entendimiento entre el Reino de España y el Reino Unido el 29 de noviembre de 2018, sobre los derechos de los ciudadanos. Memorandum of Understanding on citizens' rights.

DOCUMENTO 9. Memorando de Entendimiento entre el Reino de España y el Reino Unido el 29 de noviembre de 2018, sobre cooperación en materia medioambiental. Memorandum of Understanding on cooperation on environmental matters.

DOCUMENTO 10. Memorando de Entendimiento entre el Reino de España y el Reino Unido el 29 de noviembre de 2018, sobre el tabaco y otros productos. Memorandum of Understanding on tobacco and other products. 


\section{COMUNICACIONES PROCEDENTES DE LAS INSTITUCIONES, ÓRGANOS Y ORGANISMOS DE LA UNIÓN EUROPEA}

\section{CONSEJO}

\section{ACUERDO}

sobre la retirada del Reino Unido de Gran Bretaña e Irlanda del Norte de la Unión Europea y de la Comunidad Europea de la Energía Atómica

(2019/C $66 \mathrm{I} / 01)$

PREÁMBULO

LA UNIÓN EUROPEA Y LA COMUNIDAD EUROPEA DE LA ENERGÍA ATÓMICA

Y

EL REINO UNIDO DE GRAN BRETAÑA E IRLANDA DEL NORTE

CONSIDERANDO que el 29 de marzo de 2017 el Reino Unido de Gran Bretaña e Irlanda del Norte (en lo sucesivo, "Reino Unido"), tras el resultado de un referéndum celebrado en el Reino Unido y su decisión soberana de abandonar la Unión Europea, notificó su intención de retirarse de la Unión Europea (en lo sucesivo, "Unión") y de la Comunidad Europea de la Energía Atómica (en lo sucesivo, "Euratom») de conformidad con el artículo 50 del Tratado de la Unión Europea (en lo sucesivo, "TUE»), que se aplica a la Euratom en virtud del artículo 106 bis del Tratado constitutivo de la Comunidad Europea de la Energía Atómica (en lo sucesivo, "Tratado Euratom»),

DESEANDO establecer la forma de la retirada del Reino Unido de la Unión y de la Euratom, teniendo cuenta el marco de sus relaciones futuras,

TOMANDO NOTA de las orientaciones del Consejo Europeo de 29 de abril y 15 de diciembre de 2017 y de 23 de marzo de 2018, según las cuales la Unión debe celebrar un acuerdo por el que se establezcan las disposiciones de la retirada del Reino Unido de la Unión y de la Euratom,

RECORDANDO que, en virtud del artículo 50 del TUE, en relación con el artículo 106 bis del Tratado Euratom, y a reserva de las disposiciones establecidas en el presente Acuerdo, el Derecho de la Unión y de la Euratom en su totalidad dejará de aplicarse al Reino Unido a partir de la fecha de entrada en vigor del presente Acuerdo,

DESTACANDO que el objetivo del presente Acuerdo es garantizar una retirada ordenada del Reino Unido de la Unión y de la Euratom,

RECONOCIENDO que es necesario proporcionar protección recíproca a los ciudadanos de la Unión y a los nacionales del Reino Unido, así como a los miembros de sus familias respectivas, cuando hayan ejercido sus derechos de libre circulación antes de una fecha fijada en el presente Acuerdo, y garantizar que los derechos que les corresponden en virtud del presente Acuerdo sean exigibles y se basen en el principio de no discriminación; reconociendo asimismo que deben protegerse los derechos devengados por períodos de cotización a sistemas de seguridad social,

RESUELTOS a garantizar una retirada ordenada por medio de diversas disposiciones relativas a la separación, destinadas a evitar perturbaciones y a proporcionar seguridad jurídica a los ciudadanos y a los operadores económicos, así como a las autoridades judiciales y administrativas de la Unión y del Reino Unido, sin excluir la posibilidad de que las disposiciones pertinentes relativas a la separación sean sustituidas por el acuerdo o acuerdos sobre las relaciones futuras,

CONSIDERANDO que redunda en interés tanto de la Unión como del Reino Unido determinar un período transitorio o de ejecución durante el cual -no obstante todas las consecuencias de la retirada del Reino Unido de la Unión en lo que respecta a la participación del Reino Unido en las instituciones, órganos y organismos de la Unión, en especial el fin, en la fecha de entrada en vigor del presente Acuerdo, de los mandatos de todos los miembros de las instituciones, órganos 
y organismos de la Unión que se hubiesen nombrado, designado o elegido por la pertenencia del Reino Unido a la Unión- el Derecho de la Unión, incluidos los acuerdos internacionales, debe ser aplicable al y en el Reino Unido, y, por regla general, desplegar los mismos efectos en relación con los Estados miembros, para evitar perturbaciones en el período durante el cual se negociará el acuerdo o acuerdos sobre las relaciones futuras,

RECONOCIENDO que, aunque el Derecho de la Unión se aplique al y en el Reino Unido durante el período transitorio, las características específicas del Reino Unido, en cuanto Estado que se ha retirado de la Unión, implican que será importante que el Reino Unido pueda tomar medidas para preparar y establecer nuevos acuerdos internacionales propios, inclusive en ámbitos de competencia exclusiva de la Unión, a condición de que dichos acuerdos no entren en vigor ni se apliquen durante ese período, a menos que la Unión lo autorice,

RECORDANDO que la Unión y el Reino Unido han acordado respetar los compromisos mutuos contraídos cuando el Reino Unido aún era miembro de la Unión a través de una liquidación financiera única,

CONSIDERANDO que, para garantizar una interpretación y aplicación correctas del presente Acuerdo y el cumplimiento de las obligaciones derivadas del mismo, es esencial establecer disposiciones que aseguren la gobernanza general, en particular normas vinculantes de solución de controversias y de garantía del cumplimiento que respeten plenamente la autonomía de los ordenamientos jurídicos respectivos de la Unión y del Reino Unido así como la condición de tercer país del Reino Unido,

RECONOCIENDO que, para que la retirada del Reino Unido de la Unión sea ordenada, también es necesario establecer, en protocolos separados del presente Acuerdo, disposiciones duraderas para dar respuesta a situaciones muy específicas relativas a Irlanda / Irlanda del Norte y a las zonas de soberanía en Chipre,

RECONOCIENDO, además, que, para que la retirada del Reino Unido de la Unión sea ordenada, también es necesario establecer, en un protocolo separado del presente Acuerdo, disposiciones específicas respecto de Gibraltar que sean aplicables, en particular, durante el período transitorio,

RECALCANDO que el presente Acuerdo se fundamenta en un equilibrio global de beneficios, derechos y obligaciones para la Unión y el Reino Unido,

TOMANDO NOTA de que, en paralelo al presente Acuerdo, las Partes han efectuado una Declaración Política en la que se expone el marco de las relaciones futuras entre la Unión Europea y el Reino Unido de Gran Bretaña e Irlanda del Norte,

CONSIDERANDO que existe la necesidad, tanto para el Reino Unido como para la Unión, de adoptar todas las medidas necesarias para empezar, tan pronto como sea posible después del 29 de marzo de 2019 , las negociaciones formales de uno o varios acuerdos que regulen sus relaciones futuras, con el fin de garantizar que, en la medida de lo posible, dichos acuerdos se apliquen a partir del final del período transitorio,

\section{HAN CONVENIDO EN LO SIGUIENTE:}

\section{PRIMERA PARTE}

\section{DISPOSICIONES COMUNES}

Artículo 1

\section{Objetivo}

El presente Acuerdo establece las disposiciones relativas a la retirada del Reino Unido de Gran Bretaña e Irlanda del Norte (en lo sucesivo, "Reino Unido") de la Unión Europea (en lo sucesivo, "Unión") y de la Comunidad Europea de la Energía Atómica (en lo sucesivo, "Euratom»).

Artículo 2

\section{Definiciones}

A efectos del presente Acuerdo, se entenderá por:

a) "Derecho de la Unión":

i) el Tratado de la Unión Europea (en lo sucesivo, "TUE»), el Tratado de Funcionamiento de la Unión Europea (en lo sucesivo, "TFUE») y el Tratado constitutivo de la Comunidad Europea de la Energía Atómica (en lo sucesivo, "Tratado Euratom»), tal como han sido modificados o complementados, así como los Tratados de Adhesión y la Carta de los Derechos Fundamentales de la Unión Europea, denominados conjuntamente "los Tratados",

ii) los principios generales del Derecho de la Unión, 
iii) los actos adoptados por las instituciones, órganos u organismos de la Unión,

iv) los acuerdos internacionales en los que sea Parte la Unión y los acuerdos internacionales celebrados por los Estados miembros en nombre de la Unión,

v) los acuerdos celebrados entre Estados miembros en calidad de Estados miembros de la Unión,

vi) los actos de los representantes de los Gobiernos de los Estados miembros reunidos en el seno del Consejo Europeo o del Consejo de la Unión Europea (en lo sucesivo, "Consejo"),

vii) las declaraciones realizadas a raíz de las conferencias intergubernamentales en las que se adoptaron los Tratados;

b) "Estados miembros»: el Reino de Bélgica, la República de Bulgaria, la República Checa, el Reino de Dinamarca, la República Federal de Alemania, la República de Estonia, Irlanda, la República Helénica, el Reino de España, la República Francesa, la República de Croacia, la República Italiana, la República de Chipre, la República de Letonia, la República de Lituania, el Gran Ducado de Luxemburgo, Hungría, la República de Malta, el Reino de los Países Bajos, la República de Austria, la República de Polonia, la República Portuguesa, Rumanía, la República de Eslovenia, la República Eslovaca, la República de Finlandia y el Reino de Suecia;

c) "ciudadano de la Unión": toda persona que tenga la nacionalidad de un Estado miembro;

d) "nacional del Reino Unido": un nacional del Reino Unido, como se define en la nueva declaración del Gobierno del Reino Unido de Gran Bretaña e Irlanda del Norte, de 31 de diciembre de 1982, sobre la definición del término "nacionales" $\left.{ }^{1}\right)$ y en la declaración n. ${ }^{\circ} 63$ aneja al Acta Final de la conferencia intergubernamental que adoptó el Tratado de Lisboa $\left({ }^{2}\right)$;

e) "período transitorio": el período previsto en el artículo 126;

f) "día»: un día natural, salvo disposición en contrario del presente Acuerdo o de disposiciones del Derecho de la Unión que resulten de aplicación en virtud del presente Acuerdo.

Artículo 3

\section{Ámbito de aplicación territorial}

1. Salvo disposición en contrario del presente Acuerdo o del Derecho de la Unión que resulte de aplicación en virtud del presente Acuerdo, se entenderá que las referencias al Reino Unido o a su territorio en el presente Acuerdo se refieren a:

a) el Reino Unido;

b) Gibraltar, en la medida en que el Derecho de la Unión fuese de aplicación a Gibraltar antes de la fecha de entrada en vigor del presente Acuerdo;

c) las islas del Canal y la isla de Man, en la medida en que el Derecho de la Unión fuese de aplicación a estas antes de la fecha de entrada en vigor del presente Acuerdo

d) las zonas de soberanía de Akrotiri y Dhekelia en Chipre, en la medida en que sea necesario para garantizar el cumplimiento de las disposiciones establecidas en el Protocolo relativo a las zonas de soberanía del Reino Unido de Gran Bretaña e Irlanda del Norte en Chipre adjunto al Acta relativa a las condiciones de adhesión de la República Checa, la República de Estonia, la República de Chipre, la República de Letonia, la República de Lituania, la República de Hungría, la República de Malta, la República de Polonia, la República de Eslovenia y la República Eslovaca a la Unión Europea;

e) los países y territorios de ultramar recogidos en el anexo II del TFUE que mantienen relaciones especiales con el Reino Unido $\left({ }^{3}\right)$, respecto de las disposiciones del presente Acuerdo referentes al régimen especial de asociación de los países y territorios de ultramar con la Unión.

2. Salvo disposición en contrario del presente Acuerdo o del Derecho de la Unión que resulte de aplicación en virtud del presente Acuerdo, se entenderá que las referencias a los Estados miembros, o a su territorio, en el presente Acuerdo abarcan los territorios de los Estados miembros a los que se aplican los Tratados como se dispone en el artículo 355 del TFUE.

(1) DO C 23 de 28.1.1983, p. 1

(2) DO C 306 de 17.12 .2007 , p. 270

$\left({ }^{2}\right)$ DO C 306 de 17.12.2007, p. 270.
$\left({ }^{3}\right)$ Anguila, Bermudas, Islas Caimán, Georgia del Sur e Islas Sandwich del Sur, Islas Malvinas (Falkland), Pitcairn, Islas Turcas y Caicos, Islas Vírgenes británicas, Montserrat, Santa Elena, Ascensión y Tristán da Cunha, territorio antártico británico y territorios británicos del Océano Índico. 
Artículo 4

\section{Métodos y principios relativos a los efectos, la ejecución y la aplicación del presente Acuerdo}

1. Las disposiciones del presente Acuerdo y las disposiciones del Derecho de la Unión que resulten de aplicación en virtud del presente Acuerdo producirán los mismos efectos jurídicos para el Reino Unido, y en su territorio, que los que produzcan en la Unión y en sus Estados miembros.

Por lo tanto, las personas físicas o jurídicas podrán, en particular, invocar directamente las disposiciones contenidas en el presente Acuerdo, o indicadas en él, que cumplan las condiciones para tener efecto directo en virtud del Derecho de la Unión.

2. El Reino Unido garantizará el cumplimiento del apartado 1, incluido en lo relativo a las competencias de sus autoridades judiciales y administrativas para no aplicar disposiciones nacionales incoherentes o incompatibles, por medio del Derecho primario nacional.

3. Las disposiciones del presente Acuerdo que se refieran al Derecho de la Unión o a conceptos o disposiciones de este se interpretarán y aplicarán conforme a los métodos y principios generales del Derecho de la Unión.

4. Las disposiciones del presente Acuerdo que se refieran al Derecho de la Unión, o a conceptos o disposiciones de este, se interpretarán, en el marco de su ejecución y aplicación, de conformidad con la jurisprudencia pertinente del Tribunal de Justicia de la Unión Europea dictada antes del final del período transitorio.

5. Al interpretar y aplicar el presente Acuerdo, las autoridades judiciales y administrativas del Reino Unido tendrán debidamente en cuenta la jurisprudencia pertinente del Tribunal de Justicia de la Unión Europea dictada después del final del período transitorio.

Artículo 5

\section{Buena fe}

La Unión y el Reino Unido, con pleno respeto mutuo y de buena fe, se asistirán mutuamente en el cumplimiento de las tareas derivadas del presente Acuerdo.

Adoptarán todas las medidas apropiadas, tanto de índole general como particular, para asegurar el cumplimiento de las obligaciones derivadas del presente Acuerdo y se abstendrán de toda medida que pueda poner en peligro la consecución de los objetivos del presente Acuerdo.

El presente artículo no afecta a la aplicación del Derecho de la Unión en virtud del presente Acuerdo, en particular al principio de cooperación leal.

\section{Artículo 6}

\section{Referencias al Derecho de la Unión}

1. Con excepción de la cuarta y quinta partes, salvo disposición en contrario del presente Acuerdo, todas las referencias en el presente Acuerdo al Derecho de la Unión se entenderán como referencias al Derecho de la Unión, incluidas sus modificaciones y sustituciones, que sea de aplicación en el último día del período transitorio.

2. Cuando el presente Acuerdo se refiera a actos de la Unión o a disposiciones de estos, se entenderá que dicha referencia incluye, en su caso, una referencia al Derecho de la Unión o a disposiciones de este que, aunque hayan sido sustituidas por el acto referido, siguen aplicándose conforme a dicho acto.

3. A efectos del presente Acuerdo, se entenderá que las referencias a disposiciones del Derecho de la Unión que resulten de aplicación en virtud del presente Acuerdo incluyen las referencias a los correspondientes actos de la Unión que completen o ejecuten dichas disposiciones.

\section{Artículo 7}

\section{Referencias a la Unión y a los Estados miembros}

1. A efectos del presente Acuerdo, se entenderá que todas las referencias a los Estados miembros y a las autoridades competentes de estos en las disposiciones del Derecho de la Unión que resulten de aplicación en virtud del presente Acuerdo incluyen al Reino Unido y sus autoridades competentes, salvo en lo que respecta a:

a) la designación, el nombramiento o la elección de miembros de las instituciones, órganos y organismos de la Unión, así como la participación en el proceso decisorio y la asistencia a las reuniones de las instituciones; 
b) la participación en el proceso decisorio y la gobernanza de los órganos y organismos de la Unión;

c) la asistencia a las reuniones de los comités a que se refiere el artículo 3, apartado 2, del Reglamento (UE) n. ${ }^{\circ}$ 182/2011 del Parlamento Europeo y del Consejo $\left({ }^{4}\right)$, a las reuniones de los grupos de expertos de la Comisión o de otras entidades similares, o a las reuniones de los grupos de expertos o entidades similares de los órganos y organismos de la Unión, salvo disposición en contrario del presente Acuerdo.

2. Se entenderá que toda referencia a la Unión incluye a la Euratom salvo disposición en contrario del presente Acuerdo.

Artículo 8

\section{Acceso a redes, sistemas de información y bases de datos}

Salvo disposición en contrario del presente Acuerdo, al final del período transitorio el Reino Unido dejará de tener derecho de acceso a toda red, sistema de información y base de datos establecidos con base en el Derecho de la Unión. El Reino Unido adoptará las medidas adecuadas para garantizar que no accede a ninguna red, sistema de información o base de datos respecto de los que deje de tener derecho de acceso.

\section{Comités especializados}

1. Se crean los comités especializados siguientes:

a) el Comité de derechos de los ciudadanos;

b) el Comité sobre otras disposiciones de separación;

c) el Comité sobre cuestiones relacionadas con la aplicación del Protocolo sobre Irlanda/Irlanda del Norte;

d) el Comité sobre cuestiones relacionadas con la aplicación del Protocolo sobre las zonas de soberanía en Chipre;

e) el Comité sobre cuestiones relacionadas con la aplicación del Protocolo sobre Gibraltar; y

f) el Comité sobre las disposiciones financieras.

Dichos comités especializados estarán compuestos por representantes de la Unión y representantes del Reino Unido.

2. Los trabajos de los comités especializados se regularán por el Reglamento interno establecido en el anexo VIII del presente Acuerdo.

Salvo disposición en contrario del presente Acuerdo, o salvo que los copresidentes decidan otra cosa, los comités especializados se reunirán al menos una vez al año. Se podrán celebrar reuniones adicionales a petición de la Unión, del Reino Unido o del Comité Mixto. Estarán copresididos por representantes de la Unión y del Reino Unido. Los comités especializados fijarán su calendario de reuniones y su orden del día de común acuerdo. Los comités especializados podrán elaborar proyectos de decisiones y de recomendaciones y remitirlos al Comité Mixto para su adopción.

3. La Unión y el Reino Unido velarán por que sus respectivos representantes en los comités especializados cuenten con los conocimientos técnicos adecuados respecto de los asuntos que se debatan.

4. Los comités especializados comunicarán al Comité Mixto sus calendarios de reuniones y sus órdenes del día con una antelación suficiente e informarán al Comité Mixto de los resultados y las conclusiones de cada una de sus reuniones. La creación o la existencia de un comité especializado no será óbice para que la Unión o el Reino Unido sometan cualquier asunto directamente al Comité Mixto. 
Artículo 179

\section{Revisión de las medidas adoptadas después de las medidas correctoras temporales}

1. Cuando la parte demandante haya suspendido obligaciones conforme al artículo 178 o cuando el panel de arbitraje haya impuesto una multa coercitiva a la parte demandada con arreglo al artículo 178, apartado 1, la parte demandada notificará a la parte demandante cualquier medida que haya adoptado con objeto de cumplir el laudo del panel de arbitraje y su petición de que se ponga fin a la suspensión de obligaciones aplicada por la parte demandante o a la multa coercitiva.

2. Si, en el plazo de cuarenta y cinco días desde la fecha de presentación de la notificación, la Unión y el Reino Unido no alcanzan un acuerdo que dirima si la medida notificada conlleva la conformidad de la parte demandada con las disposiciones del presente Acuerdo, cualquiera de las partes podrá pedir por escrito al panel de arbitraje original que resuelva sobre el asunto. Dicha petición se notificará simultáneamente a la otra parte. El laudo del panel de arbitraje se notificará a la Unión y al Reino Unido y al Comité Mixto en el plazo de setenta y cinco días desde la fecha de presentación de la petición.

Si el panel de arbitraje resuelve que la parte demandada ha alcanzado la conformidad con el presente Acuerdo, o si la parte demandante no pide, en el plazo de cuarenta y cinco días desde la presentación de la notificación a que se refiere el apartado 1, que el panel de arbitraje original resuelva sobre el asunto:

a) la suspensión de obligaciones finalizará en el plazo de quince días desde el laudo del panel de arbitraje o desde que expire el plazo de cuarenta y cinco días;

b) la multa coercitiva finalizará el día siguiente al del laudo del panel de arbitraje o al de expiración del plazo de cuarenta y cinco días.

3. En caso de que el panel de arbitraje original, o alguno de sus miembros, no puedan reunirse nuevamente para resolver una petición presentada con arreglo al apartado 2, se constituirá un nuevo panel de arbitraje de la forma que establece el artículo 171. El plazo para notificar el laudo será en ese caso de noventa días desde la fecha de constitución del nuevo panel de arbitraje.

4. Cuando un asunto llevado ante el panel de arbitraje en virtud del apartado 2 plantee una cuestión relacionada con la interpretación de un concepto del Derecho de la Unión o una cuestión relacionada con la interpretación de una disposición del Derecho de la Unión a que se refiera el presente Acuerdo, se aplicará mutatis mutandis el artículo 174.

Artículo 180

\section{Decisiones y laudos del panel de arbitraje}

1. El panel de arbitraje hará todo lo posible para tomar sus decisiones por consenso. Cuando, no obstante lo anterior, no pueda alcanzarse una decisión por consenso, el asunto en cuestión se decidirá por mayoría de votos. Sin embargo, en ningún caso se publicarán votos particulares de los miembros de un panel de arbitraje.

2. Cualquier laudo del panel de arbitraje será vinculante para la Unión y el Reino Unido. El laudo establecerá los hechos probados, la aplicabilidad de las disposiciones pertinentes del presente Acuerdo y la motivación que fundamente cualquier veredicto y conclusión. La Unión y el Reino Unido harán públicos en su integridad los laudos y decisiones del panel de arbitraje, a reserva de la protección de la información confidencial.

Artículo 181

\section{Miembros de un panel de arbitraje}

1. Los miembros de un panel de arbitraje serán independientes, actuarán a título personal y no aceptarán instrucciones de ninguna organización o gobierno, y cumplirán el Código de Conducta establecido en el anexo IX, parte B. El Comité Mixto podrá modificar dicho Código de Conducta.

2. Los miembros de un panel de arbitraje, a partir de la constitución de este, disfrutarán de la inmunidad de jurisdicción en la Unión y en el Reino Unido con respecto a sus actuaciones en el ejercicio de las funciones que les correspondan en dicho panel de arbitraje.

TÍTULO IV

\section{Disposiciones finales}

Artículo 182

\section{Protocolos y anexos}

El Protocolo sobre Irlanda/Irlanda del Norte, el Protocolo sobre las zonas de soberanía del Reino Unido en Chipre, el Protocolo sobre Gibraltar y los anexos I a IX forman parte integrante del presente Acuerdo. 
Artículo 183

\section{Textos auténticos y depositario}

El presente Acuerdo se redacta en un ejemplar único, en lenguas alemana, búlgara, checa, croata, danesa, eslovaca, eslovena, española, estonia, finesa, francesa, griega, húngara, inglesa, irlandesa, italiana, letona, lituana, maltesa, neerlandesa, polaca, portuguesa, rumana y sueca, siendo cada uno de los textos en estas lenguas igualmente auténtico.

El Secretario General del Consejo será el depositario del presente Acuerdo.

Artículo 184

\section{Negociaciones sobre las relaciones futuras}

La Unión y el Reino Unido, de buena fe y respetando plenamente sus respectivos ordenamientos jurídicos, se esforzarán al máximo para tomar las medidas necesarias para negociar con celeridad los acuerdos que regulen sus relaciones futuras a que se refiere la Declaración Política de 25 de noviembre de 2018 y para llevar a cabo los procedimientos pertinentes para la ratificación o la celebración de esos acuerdos, con el fin de garantizar que dichos acuerdos se apliquen, en la medida de lo posible, a partir del final del período transitorio.

Artículo 185

\section{Entrada en vigor y aplicación}

El presente Acuerdo entrará en vigor el 30 de marzo de 2019. En caso de que, con anterioridad a esa fecha, el depositario del presente Acuerdo no haya recibido la notificación escrita de la conclusión de los trámites internos necesarios por parte de la Unión y del Reino Unido, el presente Acuerdo no entrará en vigor.

En el momento de la notificación escrita a que se refiere el párrafo primero, la Unión, en relación con todo aquel Estado miembro que haya alegado motivos relacionados con los principios fundamentales del Derecho nacional de dicho Estado miembro, podrá declarar que, durante el período transitorio, además de los motivos para la no ejecución de una orden de detención europea mencionados en la Decisión Marco 2002/584/JAI, las autoridades judiciales de ejecución de dicho Estado miembro podrán denegar la entrega de sus nacionales al Reino Unido en virtud de una orden de detención europea. En tal caso, el Reino Unido podrá declarar, a más tardar un mes después de la recepción de la declaración de la Unión, que sus autoridades judiciales de ejecución podrán denegar la entrega de sus nacionales a dicho Estado miembro.

La segunda y tercera partes, con excepción del artículo 19, el artículo 34, apartado 1, el artículo 44, y el artículo 96 , apartado 1, así como el título I de la sexta parte y los artículos 169 a 181, se aplicarán a partir del final del período transitorio.

El Protocolo sobre Irlanda/Irlanda del Norte se aplicará a partir del final del período transitorio, con excepción de las disposiciones del Protocolo que se indican a continuación, que se aplicarán a partir de la entrada en vigor del presente Acuerdo:

- artículos 1, 2 y 3 ,

— artículo 6, apartado 1, párrafo tercero, última frase, párrafo cuarto, párrafo quinto, última frase, y párrafo sexto,

- artículo 6, apartado 2, párrafo primero, segunda frase,

- artículo 12, apartado 2, última frase,

- artículo 14, apartado 3,

- artículo 16 ,

- artículo 17 , apartados 1 a 4 y 6 ,

- artículo 21 ,

- artículo 4, apartado 3, tercera frase, y artículo 5, apartado 2, del anexo 2,

- artículo 4, apartado 1, segunda frase, artículo 8, apartado 1, y artículo 13, párrafo segundo, primera frase, del anexo 3 ,

- artículo 1, apartado 4, artículo 2, apartado 3, artículo 7, apartado 2, última frase, y artículo 8, párrafo primero, del anexo 4, y

- párrafo primero del anexo 9. 


\section{DOCUMENTACIÓN II}

Brexity Gibraltar - Tratado de retirada, Protocolo, Tratado Fiscal y MOUs (2018-2020)

\section{DOC}

El Protocolo sobre las zonas de soberanía del Reino Unido de Gran Bretaña e Irlanda del Norte en Chipre, con excepción de su artículo 11 , se aplicará a partir del final del período transitorio.

El Protocolo sobre Gibraltar, con excepción de su artículo 1, dejará de aplicarse al final del período transitorio.

Hecho el ... 


\title{
INFORMATION FROM EUROPEAN UNION INSTITUTIONS, BODIES, OFFICES AND AGENCIES
}

\section{COUNCIL}

\section{AGREEMENT}

on the withdrawal of the United Kingdom of Great Britain and Northern Ireland from the European Union and the European Atomic Energy Community

\author{
(2019/C $66 \mathrm{I} / 01)$
}

PREAMBLE

THE EUROPEAN UNION AND THE EUROPEAN ATOMIC ENERGY COMMUNITY

AND

THE UNITED KINGDOM OF GREAT BRITAIN AND NORTHERN IRELAND,

CONSIDERING that on 29 March 2017 the United Kingdom of Great Britain and Northern Ireland ('United Kingdom'), following the outcome of a referendum held in the United Kingdom and its sovereign decision to leave the European Union, notified its intention to withdraw from the European Union ('Union') and the European Atomic Energy Community ('Euratom') in accordance with Article 50 of the Treaty on European Union ('TEU'), which applies to Euratom by virtue of Article 106a of the Treaty establishing the European Atomic Energy Community ('Euratom Treaty'),

WISHING to set out the arrangements for the withdrawal of the United Kingdom from the Union and Euratom, taking account of the framework for their future relationship,

NOTING the guidelines of 29 April and 15 December 2017 and of 23 March 2018 provided by the European Council in the light of which the Union is to conclude the Agreement setting out the arrangements for the withdrawal of the United Kingdom from the Union and Euratom,

RECALLING that, pursuant to Article 50 TEU, in conjunction with Article 106a of the Euratom Treaty, and subject to the arrangements laid down in this Agreement, the law of the Union and of Euratom in its entirety ceases to apply to the United Kingdom from the date of entry into force of this Agreement,

STRESSING that the objective of this Agreement is to ensure an orderly withdrawal of the United Kingdom from the Union and Euratom,

RECOGNISING that it is necessary to provide reciprocal protection for Union citizens and for United Kingdom nationals, as well as their respective family members, where they have exercised free movement rights before a date set in this Agreement, and to ensure that their rights under this Agreement are enforceable and based on the principle of non-discrimination; recognising also that rights deriving from periods of social security insurance should be protected,

RESOLVED to ensure an orderly withdrawal through various separation provisions aiming to prevent disruption and to provide legal certainty to citizens and economic operators as well as to judicial and administrative authorities in the Union and in the United Kingdom, while not excluding the possibility of relevant separation provisions being superseded by the agreement(s) on the future relationship,

CONSIDERING that it is in the interest of both the Union and the United Kingdom to determine a transition or implementation period during which - notwithstanding all consequences of the United Kingdom's withdrawal from the Union as regards the United Kingdom's participation in the institutions, bodies, offices and agencies of the Union, in particular the end, on the date of entry into force of this Agreement, of the mandates of all members of institutions, bodies 
and agencies of the Union nominated, appointed or elected in relation to the United Kingdom's membership of the Union - Union law, including international agreements, should be applicable to and in the United Kingdom, and, as a general rule, with the same effect as regards the Member States, in order to avoid disruption in the period during which the agreement(s) on the future relationship will be negotiated,

RECOGNISING that, even if Union law will be applicable to and in the United Kingdom during the transition period, the specificities of the United Kingdom as a State having withdrawn from the Union mean that it will be important for the United Kingdom to be able to take steps to prepare and establish new international arrangements of its own, including in areas of Union exclusive competence, provided such agreements do not enter into force or apply during that period, unless so authorised by the Union,

RECALLING that the Union and the United Kingdom have agreed to honour the mutual commitments undertaken while the United Kingdom was a member of the Union through a single financial settlement,

CONSIDERING that in order to guarantee the correct interpretation and application of this Agreement and compliance with the obligations under this Agreement, it is essential to establish provisions ensuring overall governance, in particular binding dispute-settlement and enforcement rules that fully respect the autonomy of the respective legal orders of the Union and of the United Kingdom as well as the United Kingdom's status as a third country,

ACKNOWLEDGING that, for an orderly withdrawal of the United Kingdom from the Union, it is also necessary to establish, in separate protocols to this Agreement, durable arrangements addressing the very specific situations relating to Ireland/Northern Ireland and to the Sovereign Base Areas in Cyprus,

ACKNOWLEDGING further that, for an orderly withdrawal of the United Kingdom from the Union, it is also necessary to establish, in a separate protocol to this Agreement, the specific arrangements in respect of Gibraltar applicable in particular during the transition period,

UNDERLINING that this Agreement is founded on an overall balance of benefits, rights and obligations for the Union and the United Kingdom,

NOTING that in parallel with this Agreement, the Parties have made a Political Declaration setting out the framework for the future relationship between the European Union and the United Kingdom of Great Britain and Northern Ireland,

CONSIDERING that there is a need for both the United Kingdom and the Union to take all necessary steps to begin as soon as possible after 29 March 2019 the formal negotiations of one or several agreements governing their future relationship with a view to ensuring that, to the extent possible, those agreements apply from the end of the transition period,

HAVE AGREED AS FOLLOWS:

PART ONE

\section{COMMON PROVISIONS}

\section{Article 1}

\section{Objective}

This Agreement sets out the arrangements for the withdrawal of the United Kingdom of Great Britain and Northern Ireland ('United Kingdom') from the European Union ('Union') and from the European Atomic Energy Community ('Euratom').

Article 2

\section{Definitions}

For the purposes of this Agreement, the following definitions shall apply:

(a) 'Union law' means:

(i) the Treaty on European Union ('TEU'), the Treaty on the Functioning of the European Union ('TFEU') and the Treaty establishing the European Atomic Energy Community ('Euratom Treaty'), as amended or supplemented, as well as the Treaties of Accession and the Charter of Fundamental Rights of the European Union, together referred to as 'the Treaties';

(ii) the general principles of the Union's law; 
(iii) the acts adopted by the institutions, bodies, offices or agencies of the Union;

(iv) the international agreements to which the Union is party and the international agreements concluded by the Member States acting on behalf of the Union;

(v) the agreements between Member States entered into in their capacity as Member States of the Union;

(vi) acts of the Representatives of the Governments of the Member States meeting within the European Council or the Council of the European Union ('Council');

(vii) the declarations made in the context of intergovernmental conferences which adopted the Treaties;

(b) 'Member States' means the Kingdom of Belgium, the Republic of Bulgaria, the Czech Republic, the Kingdom of Denmark, the Federal Republic of Germany, the Republic of Estonia, Ireland, the Hellenic Republic, the Kingdom of Spain, the French Republic, the Republic of Croatia, the Italian Republic, the Republic of Cyprus, the Republic of Latvia, the Republic of Lithuania, the Grand Duchy of Luxembourg, Hungary, the Republic of Malta, the Kingdom of the Netherlands, the Republic of Austria, the Republic of Poland, the Portuguese Republic, Romania, the Republic of Slovenia, the Slovak Republic, the Republic of Finland and the Kingdom of Sweden;

(c) 'Union citizen' means any person holding the nationality of a Member State;

(d) 'United Kingdom national' means a national of the United Kingdom, as defined in the New Declaration by the Government of the United Kingdom of Great Britain and Northern Ireland of 31 December 1982 on the definition of the term 'nationals' ( $\left.{ }^{1}\right)$ together with Declaration No 63 annexed to the Final Act of the intergovernmental conference which adopted the Treaty of Lisbon $\left({ }^{2}\right)$;

(e) 'transition period' means the period provided in Article 126;

(f) 'day' means a calendar day, unless otherwise provided in this Agreement or in provisions of Union law made applicable by this Agreement.

Article 3

\section{Territorial scope}

1. Unless otherwise provided in this Agreement or in Union law made applicable by this Agreement, any reference in this Agreement to the United Kingdom or its territory shall be understood as referring to:

(a) the United Kingdom;

(b) Gibraltar, to the extent that Union law was applicable to it before the date of entry into force of this Agreement;

(c) the Channel Islands and the Isle of Man, to the extent that Union law was applicable to them before the date of entry into force of this Agreement;

(d) the Sovereign Base Areas of Akrotiri and Dhekelia in Cyprus, to the extent necessary to ensure the implementation of the arrangements set out in the Protocol on the Sovereign Base Areas of the United Kingdom of Great Britain and Northern Ireland in Cyprus annexed to the Act concerning the conditions of accession of the Czech Republic, the Republic of Estonia, the Republic of Cyprus, the Republic of Latvia, the Republic of Lithuania, the Republic of Hungary, the Republic of Malta, the Republic of Poland, the Republic of Slovenia and the Slovak Republic to the European Union;

(e) the overseas countries and territories listed in Annex II to the TFEU having special relations with the United Kingdom ( $\left.{ }^{3}\right)$, where the provisions of this Agreement relate to the special arrangements for the association of the overseas countries and territories with the Union.

2. Unless otherwise provided in this Agreement or in Union law made applicable by this Agreement, any reference in this Agreement to Member States, or their territory, shall be understood as covering the territories of the Member States to which the Treaties apply as provided in Article 355 TFEU.

(1) OJ C 23, 28.1.1983, p. 1

$(2)$ OJ C $306,17.12 .2007$, p. 270

(3) Anguilla, Bermuda, British Antarctic Territory, British Indian Ocean Territory, British Virgin Islands, Cayman Islands, Falkland Islands, Montserrat, Pitcairn, Saint Helena, Ascension and Tristan da Cunha, South Georgia and the South Sandwich Islands, and Turks and Caicos Islands. 


\section{Methods and principles relating to the effect, the implementation and the application of this Agreement}

1. The provisions of this Agreement and the provisions of Union law made applicable by this Agreement shall produce in respect of and in the United Kingdom the same legal effects as those which they produce within the Union and its Member States.

Accordingly, legal or natural persons shall in particular be able to rely directly on the provisions contained or referred to in this Agreement which meet the conditions for direct effect under Union law.

2. The United Kingdom shall ensure compliance with paragraph 1, including as regards the required powers of its judicial and administrative authorities to disapply inconsistent or incompatible domestic provisions, through domestic primary legislation.

3. The provisions of this Agreement referring to Union law or to concepts or provisions thereof shall be interpreted and applied in accordance with the methods and general principles of Union law.

4. The provisions of this Agreement referring to Union law or to concepts or provisions thereof shall in their implementation and application be interpreted in conformity with the relevant case law of the Court of Justice of the European Union handed down before the end of the transition period.

5. In the interpretation and application of this Agreement, the United Kingdom's judicial and administrative authorities shall have due regard to relevant case law of the Court of Justice of the European Union handed down after the end of the transition period.

Article 5

\section{Good faith}

The Union and the United Kingdom shall, in full mutual respect and good faith, assist each other in carrying out tasks which flow from this Agreement.

They shall take all appropriate measures, whether general or particular, to ensure fulfilment of the obligations arising from this Agreement and shall refrain from any measures which could jeopardise the attainment of the objectives of this Agreement.

This Article is without prejudice to the application of Union law pursuant to this Agreement, in particular the principle of sincere cooperation.

Article 6

\section{References to Union law}

1. With the exception of Parts Four and Five, unless otherwise provided in this Agreement all references in this Agreement to Union law shall be understood as references to Union law, including as amended or replaced, as applicable on the last day of the transition period.

2. Where in this Agreement reference is made to Union acts or provisions thereof, such reference shall, where relevant, be understood to include a reference to Union law or provisions thereof that, although replaced or superseded by the act referred to, continue to apply in accordance with that act.

3. For the purposes of this Agreement, references to provisions of Union law made applicable by this Agreement shall be understood to include references to the relevant Union acts supplementing or implementing those provisions.

Article 7

\section{References to the Union and to Member States}

1. For the purposes of this Agreement, all references to Member States and competent authorities of Member States in provisions of Union law made applicable by this Agreement shall be understood as including the United Kingdom and its competent authorities, except as regards:

(a) the nomination, appointment or election of members of the institutions, bodies, offices and agencies of the Union, as well as the participation in the decision-making and the attendance in the meetings of the institutions; 
(b) the participation in the decision-making and governance of the bodies, offices and agencies of the Union;

(c) the attendance in the meetings of the committees referred to in Article 3(2) of Regulation (EU) No 182/2011 of the European Parliament and of the Council $\left({ }^{4}\right)$, of Commission expert groups or of other similar entities, or in the meetings of expert groups or similar entities of bodies, offices and agencies of the Union, unless otherwise provided in this Agreement.

2. Unless otherwise provided in this Agreement, any reference to the Union shall be understood as including Euratom.

Article 165

\section{Specialised committees}

1. The following specialised committees are hereby established:

(a) the Committee on citizens' rights;

(b) the Committee on the other separation provisions;

(c) the Committee on issues related to the implementation of the Protocol on Ireland/Northern Ireland;

(d) the Committee on issues related to the implementation of the Protocol relating to the Sovereign Base Areas in Cyprus;

(e) the Committee on issues related to the implementation of the Protocol on Gibraltar; and

(f) the Committee on the financial provisions.

Those specialised committees shall comprise representatives of the Union and representatives of the United Kingdom.

2. The work of the specialised committees shall be governed by the rules of procedure set out in Annex VIII to this Agreement.

Unless otherwise provided in this Agreement, or unless the co-chairs decide otherwise, the specialised committees shall meet at least once a year. Additional meetings may be held at the request of the Union, the United Kingdom, or of the Joint Committee. They shall be co-chaired by representatives of the Union and of the United Kingdom. The specialised committees shall set their meeting schedule and agenda by mutual consent. The specialised committees may draw up draft decisions and recommendations and refer them for adoption by the Joint Committee.

3. The Union and the United Kingdom shall ensure that their respective representatives on the specialised committees have the appropriate expertise with respect to the issues under discussion.

4. The specialised committees shall inform the Joint Committee of their meeting schedules and agenda sufficiently in advance of their meetings, and shall report to the Joint Committee on the results and conclusions of each of their meetings. The creation or existence of a specialised committee shall not prevent the Union or the United Kingdom from bringing any matter directly to the Joint Committee. 


\section{Review of any measure taken after temporary remedies}

1. Where the complainant has suspended obligations in accordance with Article 178 or where the arbitration panel has imposed a penalty payment on the respondent in accordance with Article $178(1)$, the respondent shall notify the complainant of any measure it has taken to comply with the ruling of the arbitration panel and of its request for an end to the suspension of obligations applied by the complainant or to the penalty payment.

2. If the Union and the United Kingdom do not reach an agreement on whether the notified measure brings the respondent into conformity with the provisions of this Agreement within 45 days of the date of submission of the notification, either party may request the original arbitration panel in writing to rule on the matter. Such request shall be notified simultaneously to the other party. The arbitration panel ruling shall be notified to the Union and the United Kingdom and to the Joint Committee within 75 days of the date of submission of the request.

If the arbitration panel rules that the respondent has brought itself into conformity with this Agreement, or if the complainant does not, within 45 days of the submission of the notification referred to in paragraph 1, request that the original arbitration panel rule on the matter:

(a) the suspension of obligations shall be terminated within 15 days of either the ruling of the arbitration panel or the end of the 45-day period;

(b) the penalty payment shall be terminated on the day after either the ruling of the arbitration panel or the end of the 45-day period.

3. In the event of the original arbitration panel, or some of its members, being unable to reconvene to consider a request under paragraph 2, a new arbitration panel shall be established as set out in Article 171. The period for notifying the ruling shall in that case be 90 days from the date of establishment of the new arbitration panel.

4. Where a case referred to the arbitration panel pursuant to paragraph 2 raises a question of interpretation of a concept of Union law or a question of interpretation of a provision of Union law referred to in this Agreement, Article 174 shall apply mutatis mutandis.

Article 180

\section{Arbitration panel decisions and rulings}

1. The arbitration panel shall make every effort to take decisions by consensus. Where, nevertheless, a decision cannot be arrived at by consensus, the matter at issue shall be decided by majority vote. However, in no case dissenting opinions of members of an arbitration panel shall be published.

2. Any ruling of the arbitration panel shall be binding on the Union and the United Kingdom. The ruling shall set out the findings of fact, the applicability of the relevant provisions of this Agreement, and the reasoning behind any findings and conclusions. The Union and the United Kingdom shall make the arbitration panel rulings and decisions publicly available in their entirety, subject to the protection of confidential information.

Article 181

\section{Members of an arbitration panel}

1. The members of an arbitration panel shall be independent, shall serve in their individual capacity and shall not take instructions from any organisation or government, and shall comply with the Code of Conduct set out in Part B of Annex IX. The Joint Committee may amend that Code of Conduct.

2. The members of an arbitration panel shall, as from the establishment thereof, enjoy immunity from legal proceedings in the Union and the United Kingdom with respect to acts performed by them in the exercise of their functions on that arbitration panel.

TITLE IV

\section{Final provisions}

Article 182

\section{Protocols and Annexes}

The Protocol on Ireland / Northern Ireland, the Protocol relating to the Sovereign Base Areas in Cyprus, the Protocol on Gibraltar, and Annexes I to IX shall form an integral part of this Agreement. 


\section{Authentic texts and depositary}

This Agreement is drawn up in a single original in the Bulgarian, Croatian, Czech, Danish, Dutch, English, Estonian, Finnish, French, German, Greek, Hungarian, Irish, Italian, Latvian, Lithuanian, Maltese, Polish, Portuguese, Romanian, Slovak, Slovenian, Spanish and Swedish languages, the texts in each of these languages being equally authentic.

The Secretary General of the Council shall be the depositary of this Agreement.

\section{Article 184}

\section{Negotiations on the future relationship}

The Union and the United Kingdom shall use their best endeavours, in good faith and in full respect of their respective legal orders, to take the necessary steps to negotiate expeditiously the agreements governing their future relationship referred to in the Political Declaration of 25 November 2018 and to conduct the relevant procedures for the ratification or conclusion of those agreements, with a view to ensuring that those agreements apply, to the extent possible, as from the end of the transition period.

Article 185

\section{Entry into force and application}

This Agreement shall enter into force on 30 March 2019. In the event that, prior to that date, the depositary of this Agreement has not received the written notification of the completion of the necessary internal procedures by the Union and the United Kingdom, this Agreement shall not enter into force.

When making the written notification referred to in the first paragraph, the Union, in respect of any Member State which has raised reasons related to fundamental principles of national law of that Member State, may declare that, during the transition period, in addition to the grounds for non-execution of a European arrest warrant referred to in Framework Decision 2002/584/JHA, the executing judicial authorities of that Member State may refuse to surrender its nationals to the United Kingdom pursuant to a European arrest warrant. In such a case, the United Kingdom may declare, no later than 1 month after the receipt of the Union's declaration, that its executing judicial authorities may refuse to surrender its nationals to that Member State.

Parts Two and Three, with the exception of Article 19, Article 34(1), Article 44, and Article 96(1), as well as Title I of Part Six and Articles 169 to 181 , shall apply as from the end of the transition period.

The Protocol on Ireland/Northern Ireland shall apply as from the end of the transition period, with the exception of the following provisions of that Protocol, which shall apply as from the entry into force of this Agreement:

- Articles 1, 2 and 3;

- the last sentence of the third subparagraph, the fourth subparagraph, the last sentence of the fifth subparagraph, and the sixth subparagraph of Article 6(1);

- the second sentence of the first subparagraph of Article 6(2);

- the last sentence of Article 12(2);

- Article 14(3);

- Article 16;

- Article 17(1) to (4) and (6);

- Article 21;

- the third sentence of Article 4(3) and Article 5(2) of Annex 2;

- the second sentence of Article 4(1), Article 8(1) and the first sentence of the second paragraph of Article 13 of Annex 3;

- Articles 1(4) and 2(3), the last sentence of Article 7(2) and the first paragraph of Article 8 of Annex 4; and

- the first paragraph of Annex 9. 
DOCUMENTACIÓN II

Brexity Gibraltar - Tratado de retirada, Protocolo, Tratado Fiscal y MOUs (2018-2020)

The Protocol relating to the Sovereign Base Areas of the United Kingdom of Great Britain and Northern Ireland in Cyprus, with the exception of Article 11 thereof, shall apply as from the end of the transition period.

The Protocol on Gibraltar, with the exception of Article 1 thereof, shall cease to apply at the end of the transition period.

Done at .... 


\section{PROTOCOLO SOBRE GIBRALTAR}

La Unión y el Reino Unido,

RECORDANDO que el Reino Unido es responsable de las relaciones exteriores de Gibraltar y que el Derecho de la Unión es aplicable a Gibraltar en la medida establecida en el Acta de adhesión de 1972 en virtud del artículo 355, apartado 3 del TFUE,

RECORDANDO que la aplicación del presente Protocolo debe llevarse a cabo de conformidad con los respectivos ordenamientos constitucionales del Reino de España y del Reino Unido,

RECORDANDO que, en virtud del artículo 50 del TUE, en relación con el artículo 106 bis del Tratado Euratom, y sujeto a las disposiciones establecidas en el Acuerdo sobre la retirada del Reino Unido de Gran Bretaña e Irlanda del Norte de la Unión Europea y de la Comunidad Europea de la Energía Atómica (en lo sucesivo, "Acuerdo de Retirada"), el Derecho de la Unión Europea y de la Euratom, en su totalidad, deja de aplicarse al Reino Unido y, por lo tanto, a Gibraltar, a partir de la fecha de entrada en vigor del Acuerdo de Retirada,

CONSIDERANDO que es necesario garantizar una retirada ordenada de la Unión en lo que se refiere a Gibraltar,

DESTACANDO que la retirada ordenada del Reino Unido de la Unión en lo que se refiere a Gibraltar implica que debe darse una respuesta adecuada a todo posible efecto negativo en las estrechas relaciones sociales y económicas entre Gibraltar y la zona circundante, en particular el territorio de los municipios que componen la Mancomunidad de Municipios del Campo de Gibraltar en el Reino de España,

TOMANDO NOTA del compromiso del Reino Unido en lo que atañe a Gibraltar para afrontar el pago de prestaciones de forma satisfactoria a más tardar el 31 de diciembre de 2020 ,

CON EL FIN de seguir fomentando un desarrollo económico y social equilibrado en la zona, en particular en lo que se refiere a las condiciones laborales, y de seguir garantizando los niveles más elevados de protección del medio ambiente de conformidad con el Derecho de la Unión, así como de seguir reforzando la seguridad de los habitantes de la zona, en particular a través de la cooperación en materia policial y aduanera

RECONOCIENDO los beneficios para el desarrollo económico de la zona resultantes de la libre circulación de personas en virtud del Derecho de la Unión, que seguirá aplicándose durante el período transitorio,

REAFIRMANDO en particular la ambición de proteger la salud pública, y destacando la necesidad de luchar contra las graves consecuencias sanitarias, sociales y económicas del tabaquismo,

DESTACANDO igualmente la necesidad de luchar contra el fraude y el contrabando y de proteger los intereses financieros de todas las partes interesadas,

SUBRAYANDO que el presente Protocolo se entiende sin perjuicio de las respectivas posiciones jurídicas del Reino de España y del Reino Unido en relación con la soberanía y la jurisdicción,

TOMANDO NOTA de los Memorandos de Entendimiento celebrados entre el Reino de España y el Reino Unido el 29 de noviembre de 2018 en relación con los derechos de los ciudadanos, el tabaco y otros productos, la cooperación en materia de medio ambiente y la cooperación en materia policial y aduanera, así como el acuerdo alcanzado el 29 de noviembre de 2018 para celebrar un tratado en materia de fiscalidad y protección de los intereses financieros,

HAN CONVENIDO en las siguientes disposiciones, que se incorporarán como anexo al Acuerdo de Retirada:

Artículo 1

\section{Derechos de los ciudadanos}

1. El Reino de España (en lo sucesivo, "España») y el Reino Unido en lo que concierne a Gibraltar cooperarán estrechamente para preparar y respaldar la ejecución efectiva de la segunda parte del Acuerdo de Retirada sobre los derechos de los ciudadanos, que se aplica plenamente, entre otros, a los trabajadores fronterizos que residen en Gibraltar o en España, en particular en el territorio de los municipios que componen la Mancomunidad de Municipios del Campo de Gibraltar, y que, en los artículos 24 y 25, establece derechos específicos para los trabajadores fronterizos.

2. A tal efecto, las autoridades competentes deberán, con periodicidad trimestral, intercambiar información actualizada de las personas incluidas en el ámbito de aplicación de la segunda parte del Acuerdo de Retirada que residen en Gibraltar o en el territorio de los municipios que componen la Mancomunidad de Municipios del Campo de Gibraltar, incluidos, en particular, los trabajadores fronterizos. 
3. España y el Reino Unido crearán un Comité de coordinación que sirva de foro para el debate habitual entre las autoridades competentes para seguir la evolución de las cuestiones relativas al empleo y las condiciones laborales. Dicho Comité de coordinación informará de forma periódica al Comité especializado sobre cuestiones relacionadas con la aplicación del Protocolo sobre Gibraltar, creado por el artículo 165 del Acuerdo de Retirada (en lo sucesivo, "Comité especializado").

Artículo 2

\section{Derecho sobre el transporte aéreo}

El Derecho de la Unión en materia de transporte aéreo que no sea de aplicación al aeropuerto de Gibraltar antes del 30 de marzo de 2019 solo será aplicable a dicho aeropuerto a partir de la fecha que fije el Comité Mixto. El Comité Mixto adoptará la decisión al respecto una vez que el Reino Unido y España notifiquen que han alcanzado un acuerdo satisfactorio sobre la utilización del aeropuerto de Gibraltar.

Artículo 3

\section{Cuestiones fiscales y protección de los intereses financieros}

1. España y el Reino Unido establecerán, con respecto a Gibraltar, las formas de cooperación necesarias para lograr la plena transparencia en materia fiscal y en relación con la protección de los intereses financieros de todas las partes interesadas, en particular mediante el establecimiento de un sistema reforzado de cooperación administrativa para la lucha contra el fraude, el contrabando y el blanqueo de capitales y para resolver los conflictos relativos a la residencia fiscal.

2. Las normas internacionales del Grupo de los Veinte (G-20) y de la Organización para la Cooperación y el Desarrollo Económico (OCDE) relativas a la buena gobernanza fiscal, la transparencia, el intercambio de información y las prácticas fiscales perjudiciales y, en particular, los criterios en materia de contenido económico fijados por el Foro de la OCDE sobre prácticas fiscales perjudiciales, se respetarán en Gibraltar, con vistas a la participación de Gibraltar en el marco integrador de la OCDE sobre la erosión de la base imponible y el traslado de beneficios (BEPS, por sus siglas en inglés).

3. El Reino Unido velará por que su ratificación del Convenio Marco para el Control del Tabaco, adoptado en Ginebra el 21 de mayo de 2003, y el Protocolo para la Eliminación del Comercio Ilícito de Productos de Tabaco, adoptado en Seúl el 12 de noviembre de 2012, se amplíe a Gibraltar a más tardar el 30 de junio de 2020.

Sin perjuicio de lo dispuesto en el párrafo primero, el Reino Unido velará por que un sistema de trazabilidad y de medidas de seguridad relativas a los productos del tabaco que sea equivalente a los requisitos y las normas del Derecho de la Unión, esté en vigor en Gibraltar a más tardar el 30 de junio de 2020. Dicho sistema deberá garantizar el acceso recíproco a la información sobre la trazabilidad de los cigarrillos en España y en Gibraltar.

4. Con el fin de impedir y desalentar el contrabando de productos sujetos a impuestos sobre consumos específicos o impuestos especiales, el Reino Unido velará por que esté en vigor en Gibraltar, en relación con el alcohol y la gasolina, un sistema tributario que tenga por objeto impedir las actividades fraudulentas relacionadas con esos productos.

Artículo 4

\section{Protección del medio ambiente y pesca}

España y el Reino Unido crearán un Comité de coordinación que sirva de foro de debate habitual entre las autoridades competentes para cuestiones relativas en particular a la gestión de los residuos, la calidad del aire, la investigación científica y la pesca. Se invitará a la Unión a participar en las reuniones de dicho Comité de coordinación. Este Comité de coordinación informará de forma periódica al Comité especializado.

Artículo 5

\section{Cooperación en materia policial y aduanera}

España y el Reino Unido crearán un Comité de coordinación que sirva de foro para el seguimiento y la coordinación entre las autoridades competentes en cuestiones relacionadas con la cooperación en materia policial y aduanera. Se invitará a la Unión a participar en las reuniones de dicho Comité de coordinación. Este Comité de coordinación informará de forma periódica al Comité especializado. 
INMACULADA GONZÁLEZ GARCÍA; ALEJANDRO DEL VALLE GÁLVEZ;

LORENA CALVO MARISCAL; JUAN DOMINGO TORREJÓN RODRÍGUEZ;

Artículo 6

\section{Funciones del Comité especializado}

Las funciones del Comité especializado serán las siguientes:

a) facilitar la ejecución y la aplicación del presente Protocolo;

b) debatir toda cuestión suscitada por la Unión o por el Reino Unido que incida en el presente Protocolo y plantee algún tipo de dificultad;

c) estudiar los informes de los comités de coordinación a que se refiere el presente Protocolo; y

d) formular recomendaciones al Comité Mixto por lo que respecta al funcionamiento del presente Protocolo. 
The Union and the United Kingdom,

RECALLING that the United Kingdom is responsible for Gibraltar's external relations, and that Union law is applicable to Gibraltar to the extent provided in the 1972 Act of Accession by virtue of Article 355(3) TFEU,

RECALLING that this Protocol is to be implemented in accordance with the respective constitutional orders of the Kingdom of Spain and of the United Kingdom,

RECALLING that, pursuant to Article 50 TEU, in conjunction with Article 106a of the Euratom Treaty, and subject to the arrangements laid down in the Agreement on the withdrawal of the United Kingdom of Great Britain and Northern Ireland from the European Union and the European Atomic Energy Community ('Withdrawal Agreement'), the law of the European Union and of Euratom in its entirety ceases, to apply to the United Kingdom, and therefore to Gibraltar from the date of entry into force of the Withdrawal Agreement,

CONSIDERING that it is necessary to ensure an orderly withdrawal from the Union in relation to Gibraltar,

STRESSING that the orderly withdrawal of the United Kingdom from the Union in relation to Gibraltar implies that any potential negative effect on the close social and economic relations between Gibraltar and the surrounding area, in particular the territory of the municipalities that make up the Mancomunidad de Municipios del Campo de Gibraltar in the Kingdom of Spain, is adequately addressed,

TAKING NOTE of the commitment of the United Kingdom in respect of Gibraltar to address the payment of benefits in a satisfactory manner by 31 December 2020,

AIMING at continuing to promote balanced economic and social development in the area, in particular in terms of labour conditions, and continuing to ensure the highest levels of environmental protection in accordance with Union law, as well as continuing to strengthen security for the inhabitants of the area, in particular through cooperation in police and customs matters,

ACKNOWLEDGING the benefits for the economic development of the area arising from the free movement of persons under Union law, which will continue to apply during the transition period,

REAFFIRMING in particular the ambition to protect public health, and highlighting the necessity to fight against the serious health, social, and economic consequences of smoking,

EMPHASISING also the need to combat fraud and smuggling and to protect the financial interests of all the parties concerned,

UNDERLINING that this Protocol is without prejudice to the respective legal positions of the Kingdom of Spain and the United Kingdom with regard to sovereignty and jurisdiction,

TAKING NOTE of the Memoranda of Understanding concluded between the Kingdom of Spain and the United Kingdom on 29 November 2018 in relation to citizens' rights, tobacco and other products, cooperation on environmental matters and cooperation in police and customs matters, as well as the agreement reached on 29 November 2018 to conclude a treaty on taxation and the protection of financial interests,

HAVE AGREED UPON the following provisions, which shall be annexed to the Withdrawal Agreement:

Article 1

\section{Citizens' rights}

1. The Kingdom of Spain ('Spain') and the United Kingdom in respect of Gibraltar shall closely cooperate with a view to preparing and underpinning the effective implementation of Part Two of the Withdrawal Agreement on citizens' rights, which fully applies, inter alia, to frontier workers residing in Gibraltar or in Spain, in particular in the territory of the municipalities that make up the Mancomunidad de Municipios del Campo de Gibraltar, and which, in Articles 24 and 25 provide for specific rights for frontier workers.

2. To that effect, the competent authorities shall exchange up-to-date information on a quarterly basis on persons covered by Part Two of the Withdrawal Agreement who reside in Gibraltar or in the territory of the municipalities that make up the Mancomunidad de Municipios del Campo de Gibraltar, including, in particular, frontier workers. 
3. Spain and the United Kingdom shall establish a coordinating committee as a forum for regular discussion between the competent authorities to monitor matters relating to employment and labour conditions. That coordinating committee shall report to the Committee on issues related to the implementation of the Protocol on Gibraltar established by Article 165 of the Withdrawal Agreement ('Specialised Committee') on a regular basis.

\section{Article 2}

\section{Air transport law}

Union law on air transport which did not apply to the Gibraltar airport before 30 March 2019 shall only become applicable to the Gibraltar airport from the date established by the Joint Committee. The Joint Committee shall adopt the decision thereon upon notification by the United Kingdom and Spain that they have reached a satisfactory agreement on the use of the Gibraltar airport.

Article 3

\section{Fiscal matters and protection of financial interests}

1. Spain and the United Kingdom in respect of Gibraltar shall establish the forms of cooperation necessary to achieve full transparency in tax matters and in respect of the protection of financial interests of all the parties concerned, in particular by establishing an enhanced system of administrative cooperation to fight against fraud, smuggling and money laundering, and to resolve tax residence conflicts.

2. The international standards of the Group of Twenty (G20) and of the Organisation for Economic Co-operation and Development (OECD) relating to good fiscal governance, transparency, exchanges of information and harmful tax practices and in particular the economic substance criteria established by the OECD Forum on Harmful Tax Practices shall be complied with in Gibraltar, with a view to Gibraltar's participation in the OECD Inclusive Framework on base erosion and profit shifting (BEPS).

3. The United Kingdom shall ensure that its ratification of the Framework Convention on Tobacco Control, adopted in Geneva on 21 May 2003, and the Protocol to Eliminate Illicit Trade in Tobacco Products, adopted in Seoul on 12 November 2012, is extended to Gibraltar by 30 June 2020.

Without prejudice to the first subparagraph, the United Kingdom shall ensure that a system of traceability and security measures relating to tobacco products that is equivalent to the requirements and standards of Union law is in force in Gibraltar by 30 June 2020. That system shall ensure reciprocal access to the information on traceability of cigarettes in Spain and Gibraltar.

4. In order to prevent and deter the smuggling of products subject to excise duties or special taxes, the United Kingdom shall ensure that, in respect of alcohol and petrol, a tax system which aims at preventing fraudulent activities involving those products is in force in Gibraltar.

Article 4

\section{Environment protection and fishing}

Spain and the United Kingdom shall establish a coordinating committee as a forum for regular discussion between the competent authorities of issues concerning in particular waste management, air quality, scientific research and fishing. The Union shall be invited to participate in the meetings of that coordinating committee. That coordinating committee shall report to the Specialised Committee on a regular basis.

Article 5

\section{Cooperation in police and customs matters}

Spain and the United Kingdom shall establish a coordination committee as a forum for monitoring and for coordination between the competent authorities of any questions related to cooperation in police and customs matters. The Union shall be invited to participate in the meetings of that coordination committee. That coordinating committee shall report to the Specialised Committee on a regular basis. 


\section{DOCUMENTACIÓN II}

Brexity Gibraltar - Tratado de retirada, Protocolo, Tratado Fiscal y MOUs (2018-2020)

\section{DOC

Article 6

\section{Tasks of the Specialised Committee}

The Specialised Committee shall:

(a) facilitate the implementation and application of this Protocol;

(b) discuss any point of relevance to this Protocol giving rise to a difficulty and raised by the Union or the United Kingdom;

(c) examine the reports from the coordination committees referred to in this Protocol; and

(d) make recommendations to the Joint Committee as regards the functioning of this Protocol. 


\section{ACUERDO INTERNACIONAL EN MATERIA DE FISCALIDAD Y PROTECCIÓN DE LOS INTERESES FINANCIEROS ENTRE EL REINO DE ESPAÑA Y EL REINO UNIDO DE GRAN BRETAÑA E IRLANDA DEL NORTE EN RELACIÓN CON GIBRALTAR}

CONSIDERANDO que, a los efectos del presente Acuerdo, el Reino Unido actúa en su condición de Estado responsable de las relaciones exteriores de Gibraltar.

HABIDA CUENTA de que ni el presente Acuerdo, ni ninguna acción o medida tomada en aplicación o como resultado del mismo, implica una modificación de las respectivas posiciones jurídicas del Reino de España y del Reino Unido con respecto a la soberanía y jurisdicción en relación con Gibraltar,

Las Partes, decididas a mejorar la cooperación en el ámbito de la fiscalidad y la protección de los intereses financieros, han convenido en lo siguiente:

Artículo 1. Protección de los intereses financieros y buena gobernanza fiscal.

(1) Toda la legislación y las normas de la Unión Europea relativas a la transparencia, la cooperación administrativa, las prácticas fiscales perniciosas y la lucha contra el blanqueo de capitales continuarán aplicándose en Gibraltar hasta la fecha en la que el Derecho de la UE deje de ser aplicable en Gibraltar.

(2) Desde la fecha en la que el Derecho de la UE deje de ser aplicable en Gibraltar, se mantendrá en Gibraltar una legislación equivalente a la legislación vigente de la UE en esa fecha.

Artículo 2. Residencia fiscal de las personas físicas y jurídicas, entidades y otros instrumentos o formas jurídicas

\section{Personas físicas}

(1) A los efectos del presente Acuerdo, las Partes convienen en que:

(a) Las personas físicas se considerarán residentes fiscales de España o de Gibraltar de conformidad con su legislación interna, incluidas las normas relativas a la expedición de certificados fiscales que confirmen la residencia, y con sujeción a las normas que se exponen a continuación, únicamente en caso de conflicto por lo que respecta a la residencia fiscal. 
(b) Cuando por razón de lo dispuesto en la letra (a) del apartado (1) las personas físicas sean residentes de ambas Partes, su condición se determinará como sigue:

(i) Las personas físicas se considerarán residentes fiscales exclusivamente de España en cualquiera de las siguientes circunstancias:

A. si realizan más de 183 pernoctaciones durante el año natural en España. Al determinar el cómputo de pernoctaciones, las ausencias esporádicas de España y de Gibraltar se sumarán al periodo correspondiente al lugar en el que estas personas realizan la mayoría de sus pernoctaciones;

B. en caso de que, de conformidad con la legislación tributaria española, su cónyuge (del que no estén legalmente separados) o la persona física con la que se haya establecido una relación similar, así como los ascendientes o descendientes dependientes, tengan su residencia habitual en España;

C. si la única vivienda permanente a su disposición se encuentra en España; o

D. si dos tercios de los activos netos que directa o indirectamente poseen, determinados de conformidad con la legislación tributaria española, se encuentran en España.

(ii) Cuando las disposiciones del inciso (i) de la letra (b) del apartado (1) no sean concluyentes, a las personas físicas se las considerará residentes fiscales exclusivamente de España, salvo que puedan demostrar fehacientemente que poseen una vivienda permanente para su uso exclusivo en Gibraltar y que permanecen en dicho territorio más de 183 días.

(iii) El Comité Conjunto de Coordinación previsto en el Artículo 5 del presente Acuerdo se esforzará por resolver de común acuerdo las dificultades o dudas que surjan de la interpretación o la aplicación de la letra (b) del apartado (1) cuando las autoridades que lo integran así lo decidan.

(c) Las siguientes normas especiales para determinar la residencia se aplicarán en todos los casos, sin perjuicio de los criterios establecidos en los anteriores apartados:

(i) Los nacionales españoles que trasladen su residencia a Gibraltar con posterioridad a la fecha de la firma del presente 
Acuerdo se considerarán, en todos los casos, residentes fiscales exclusivamente de España.

(ii) Los nacionales no españoles que aporten prueba de su nueva residencia en Gibraltar no perderán la residencia fiscal de España. Esta norma será aplicable al periodo fiscal en que se produzca el cambio de residencia y durante los cuatro ejercicios fiscales siguientes. Este apartado no se aplicará a los nacionales no españoles que pasen menos de un ejercicio fiscal completo en España o a los gibraltareños registrados que pasen menos de cuatro años en España.

(d) A los efectos del anterior inciso (ii) de la letra (c) del apartado (1), por gibraltareños registrados se entenderá toda persona física definida en el artículo 4 de la Ley relativa a la Condición de Gibraltareño (the Gibraltarian Status Act), por lo general, ciudadanos británicos que han residido en Gibraltar durante más de diez años.

(e) Los regímenes especiales de residencia fiscal de Gibraltar para personas físicas con alto patrimonio neto (por sus siglas en inglés, HNWI), personas de la Categoría 2 (Cat 2), altos ejecutivos con cualificación especializada (por sus siglas en inglés, HEPSS), o cualquier otro régimen equivalente que pueda establecerse en el futuro, no constituirán, por sí mismos, prueba de residencia fiscal en Gibraltar a los efectos del presente Acuerdo.

\section{Personas jurídicas, entidades y otros instrumentos o formas jurídicas.}

(2) Se aplicarán las siguientes normas para determinar la residencia fiscal:

(a) Se considerará que las personas jurídicas, entidades y otros instrumentos o formas jurídicas, constituidas y gestionadas en Gibraltar, o que se rijan por su legislación, tienen residencia fiscal exclusivamente de España en cualquiera de las siguientes circunstancias:

(i) que la mayoría de los activos, en propiedad directa o indirecta, se encuentren en España o consistan en derechos que pueden o deben ejercerse en España;

(ii) que la mayor parte de la renta devengada en un año natural se derive de fuentes en España, de conformidad con el artículo 13 del texto refundido de la Ley del Impuesto sobre la Renta de no Residentes en la legislación tributaria española, con sus modificaciones ulteriores;

(iii) que la mayoría de las personas físicas encargadas de la gestión efectiva sean residentes fiscales de España; 
(iv) que la mayor parte de los derechos sobre el capital o el patrimonio neto, los derechos de voto o de participación en los beneficios se encuentre bajo el control directo o indirecto, ya sea de personas físicas que sean residentes fiscales de España, o bien de personas jurídicas, entidades u otros instrumentos o formas jurídicas vinculados a residentes fiscales de España.

(b) Los incisos anteriores (iii) y (iv) de la letra (a) del apartado (2 ) no serán de aplicación a ninguna persona jurídica, entidad ni cualquier otro instrumento o forma jurídica que haya sido constituida en Gibraltar antes del 16 de noviembre de 2018 y que, a 31 de diciembre de 2018, cuando se hayan cumplido las condiciones contenidas en los incisos (iii) o (iv) de la letra (a) del apartado (2), demuestre lo que se indica a continuación:

(i) que cuenta con un lugar fijo de negocios a través del cual la actividad se desarrolla total o parcialmente en Gibraltar, con un número suficiente de trabajadores, con la cualificación necesaria y un total adecuado de gastos operativos en relación con las actividades principales de generación de ingresos;

(ii) que está sujeta efectivamente al impuesto sobre sociedades y paga dicho impuesto sobre sus beneficios en Gibraltar, al tipo vigente de conformidad con la legislación tributaria de dicho territorio (en la actualidad el $10 \%$ o el $20 \%$ );

(iii) que durante el periodo comprendido entre la fecha de su constitución y el 31 de diciembre de 2018, ha desarrollado su actividad en o desde Gibraltar, y lo ha hecho sin interrupción ni cambio de sector desde el 1 de enero de 2011;

(iv) más del $75 \%$ de su renta respecto del ejercicio financiero inmediatamente anterior al 31 de diciembre de 2018 se devenga y deriva de fuentes en Gibraltar, de conformidad con su legislación tributaria, con sus modificaciones ulteriores; y

(v) que menos del porcentaje de ingresos que se indica a continuación, respecto del ejercicio financiero inmediatamente anterior al 31 de diciembre de 2018, procede de fuentes en España, de conformidad con el artículo 13 del texto refundido de la Ley del Impuesto sobre la Renta de no Residentes en la legislación tributaria española, con sus modificaciones ulteriores:

A. el $5 \%$ para toda persona jurídica, entidad y otro instrumento o forma jurídica cuyo volumen de negocios anual exceda de 6 millones de euros; 
B. el $10 \%$ para toda persona jurídica, entidad y otro instrumento o forma jurídica cuyo volumen de negocios anual exceda de 3 millones de euros, pero no sea superior a 6 millones de euros;

C. el $15 \%$ para toda persona jurídica, entidad y otro instrumento o forma jurídica cuyo volumen de negocios anual no exceda de 3 millones de euros.

(c) Para determinar el volumen de negocios anual del inciso (v) de la letra (b) del apartado (2), se considerará que dicho volumen incluye el de la persona jurídica, entidad $u$ otro instrumento o forma jurídica, junto con el de cualquier parte vinculada constituida en Gibraltar, cuando esta última se defina de conformidad con la Norma Internacional de Contabilidad (IAS) n. ${ }^{\circ} 24$ relativa a la información sobre partes vinculadas.

(d) Al aplicar la letra (b) del apartado (2), las autoridades fiscales de Gibraltar, designadas de conformidad con el artículo 4 del presente Acuerdo, proporcionarán a las autoridades fiscales españolas la lista de las personas jurídicas, entidades u otros instrumentos o formas jurídicas que cumplen las condiciones de los incisos (iii) o (iv) de la letra (a) del apartado (2), así como las de los incisos (i) a (v) de la letra (b) del apartado (2) a fecha de 31 de diciembre de 2018. Dicha lista contendrá información sobre la titularidad jurídica y titulares reales, así como sobre las personas físicas responsables de la gestión efectiva de tales personas jurídicas, entidades y otros instrumentos o formas jurídicas, y deberá presentarse por las autoridades fiscales gibraltareñas antes del 31 de marzo de 2020.

(e) Las personas jurídicas, entidades y otros instrumentos o formas jurídicas cuya residencia se traslade a Gibraltar después de la entrada en vigor del presente Acuerdo mantendrán, en todos los casos, la residencia fiscal exclusivamente en España.

\section{Eliminación de la doble imposición}

(3) Las autoridades competentes eliminarán, cuando proceda, la doble imposición de conformidad con lo dispuesto en su legislación interna.

\section{Artículo 3. Cooperación administrativa en materia fiscal}

(1) Las Partes aplicarán recíprocamente una cooperación administrativa reforzada con miras a intercambiar la información que sea previsiblemente pertinente para la administración, ejecución y recaudación de los tributos de toda clase y denominación, exigidos en nombre de las Partes y sus subdivisiones territoriales o administrativas, incluidas las entidades locales. 
(2) Desde la fecha en la que el Derecho de la UE deje de aplicarse en Gibraltar, las Partes aplicarán de forma recíproca medidas cuyo efecto sea equivalente a los principios y todas las modalidades que recoge la legislación de la Unión en materia de asistencia administrativa mutua en vigor en cualquier momento en la Unión Europea. En particular, la información y los mecanismos contemplados en la Directiva del Consejo 2011/16 UE de 15 de febrero de 2011 relativa a la cooperación administrativa en el ámbito de la fiscalidad y por la que se deroga la Directiva 77/799/CEE y sus modificaciones ulteriores (Directiva 2014/107/UE de 9 de diciembre de 2014, Directiva 2015/2376/UE de 8 de diciembre de 2015, Directiva 2016/881/UE de 25 de mayo de 2016 y Directiva 2018/822/UE de 25 de mayo de 2018), la Directiva 2010/24/UE de 16 de marzo de 2010 sobre la asistencia mutua en materia de cobro de los créditos correspondientes a determinados impuestos, derechos y otras medidas. Además, se aplicarán los mecanismos contemplados en los términos más amplios del Convenio Multilateral sobre Asistencia Administrativa Mutua en Materia Fiscal de la OCDE y el Consejo de Europa, así como cualquier otra norma que introduzcan en esta materia la OCDE y el G-20 en el futuro.

(3) Los órganos de enlace designados con arreglo al artículo 4 se prestarán asistencia administrativa mutua en materia fiscal en virtud del presente Acuerdo, tanto si la persona afectada es residente de una de las Partes como si no lo es de ninguna de ellas. Podrá recurrirse en todos los casos a las siguientes formas de cooperación:

(a) el intercambio de información, ya sea automático, espontáneo o previa solicitud, incluidas las inspecciones fiscales simultáneas o los controles conjuntos y la participación en inspecciones fiscales en el extranjero;

(b) la asistencia en la recaudación, incluidas las medidas cautelares, de conformidad con su respectiva legislación interna; y

(c) la entrega o el traslado de documentos.

(4) Los órganos de enlace acuerdan, además, intercambiar automáticamente información sobre las categorías de información detalladas en las letras (a) y (b) del apartado (5) y letras (a) y (b) del apartado (10).

(5) Las autoridades fiscales gibraltareñas designadas a tenor del artículo 4 de este Acuerdo proporcionarán a las autoridades fiscales españolas designadas de igual manera:

(a) Información anual de los trabajadores registrados en Gibraltar como residentes en España, detallando específicamente todos los extremos de su relación laboral subyacente o de cualquier actividad empresarial o profesional desarrollada por dichos trabajadores, 
incluidos los pormenores relativos a la duración, los términos económicos y el empleador.

(b) Información semestral sobre buques, aeronaves y vehículos de motor registrados en Gibraltar en relación con residentes fiscales en España.

(c) Acceso libre y directo a las anotaciones del Registro Mercantil de Gibraltar (Registrar of Companies in Gibraltar), de acuerdo con la Directiva relativa a la prevención de la utilización del sistema financiero para el blanqueo de capitales o la financiación del terrorismo, que modifica las Directivas 2009/138/CE y 2013/36/UE, así como al Registro de la Propiedad de Gibraltar (Gibraltar Land Registry).

(d) Acceso directo a la información que sea pública sobre titulares reales o, mediante solicitud remitida al "Commissioner of Income Tax" de Gibraltar, de empresas, personas jurídicas, sociedades de personas y fundaciones.

(e) Acceso directo acceso a la información que sea pública o esté a disposición del "Commissioner of Income Tax" de Gibraltar sobre fideicomitentes, fideicomisarios, beneficiarios y elementos patrimoniales de todo tipo de fideicomisos, así como otros instrumentos o formas jurídicas establecidas o administradas en Gibraltar, o que se rijan por su legislación, cuando los fideicomitentes, fideicomisarios, los protectores o beneficiarios, sean residentes fiscales en España o los elementos patrimoniales de cualquier tipo de fideicomiso estén situados en España.

(6) A los efectos de la letra (a) del apartado (5) anterior, la información se intercambiará en el plazo de cuatro meses desde el final del año natural en que finalice el periodo de imposición.

(7) El primer intercambio de información en virtud de la letra (a) del apartado (5) anterior, irá referido a los periodos impositivos iniciados a partir del 1 de enero de 2014 hasta la fecha de entrada en vigor del presente Acuerdo, y se realizará dentro de los cuatro meses siguientes a la fecha de entrada en vigor del presente Acuerdo.

(8) A los efectos de la letra (b) del apartado (5) anterior, la información se intercambiará semestralmente, el 31 de marzo y el 30 de septiembre, a partir de la fecha del primer intercambio en virtud del presente Acuerdo. La información intercambiada el 31 de marzo se referirá al periodo comprendido entre el 1 de julio y el 31 de diciembre del año natural anterior, y la información intercambiada el 30 de septiembre se referirá al periodo comprendido entre el 1 de enero y el 30 de junio del mismo año natural. Los intercambios realizados garantizarán la continuidad de la información ofrecida de forma que no se omita ningún periodo entre el primer intercambio de información posterior la fecha de entrada en vigor 
del presente Acuerdo y los intercambios ulteriores. Estos intercambios de información solo incluirán los datos de los nuevos registros de buques, aeronaves y vehículos de motor.

(9) El primer intercambio de información en virtud de la letra (b) del apartado (5) anterior irá referido a los periodos impositivos que correspondan a años naturales iniciados desde el 1 de enero de 2014 hasta la fecha de entrada en vigor del presente Acuerdo y se realizará dentro de los cuatro meses siguientes a la fecha de entrada en vigor del presente Acuerdo. Esta información incluirá la titularidad, el número de matrícula, el valor y la fecha de adquisición de buques, aeronaves y vehículos de motor registrados en Gibraltar.

(10) Las autoridades fiscales españolas designadas a tenor del artículo 4 del presente Acuerdo proporcionarán a las autoridades fiscales gibraltareñas designadas de igual manera los siguientes datos:

(a) Información anual de los trabajadores registrados en España como residentes en Gibraltar, detallando específicamente los extremos económicos de la relación laboral subyacente o de cualquier actividad empresarial o profesional desarrollada por dichos trabajadores, incluidos los pormenores relativos a la duración, los términos económicos, las rentas anuales y exentas y el empleador.

(b) Información semestral sobre buques, aeronaves o vehículos de motor registrados por primera vez en España en relación con residentes fiscales en Gibraltar.

(11) A los efectos de la letra (a) del apartado (10) anterior, la información se remitirá en el plazo de cuatro meses desde el final del año natural al que se refiera.

(12) El primer intercambio de información en virtud de la letra (a) del apartado (10) anterior irá referido a los periodos impositivos iniciados a partir del 1 de enero de 2014 hasta la fecha de entrada en vigor del presente Acuerdo y se realizará dentro de los cuatro meses siguientes a la fecha de entrada en vigor del presente Acuerdo.

(13) A los efectos de la letra (b) del apartado (10) anterior, la información se intercambiará semestralmente, el 31 de marzo y el 30 de septiembre. La información intercambiada el 31 de marzo se referirá al periodo comprendido entre el 1 de julio y el 31 de diciembre del año natural anterior, y la información intercambiada el 30 de septiembre se referirá al periodo comprendido entre el 1 de enero y el 30 de junio del mismo año natural. Los intercambios realizados garantizarán la continuidad de la información ofrecida de forma que no se omita ningún periodo entre el primer intercambio de información posterior a la fecha de entrada en vigor del presente Acuerdo y los intercambios ulteriores. Estos intercambios de información solo incluirán los datos de los nuevos registros de buques, aeronaves y vehículos de motor. 
(14) El primer intercambio de información en virtud de la letra (b) del apartado (10) anterior irá referido a los periodos impositivos que correspondan a años naturales iniciados desde el 1 de enero de 2014 hasta la fecha de entrada en vigor del presente Acuerdo y se realizará dentro de los cuatro meses siguientes a la fecha de entrada en vigor del presente Acuerdo. Esta información incluirá la titularidad, el número de matrícula, el valor y la fecha de adquisición de buques, aeronaves y vehículos de motor registrados en Gibraltar.

(15) A los efectos del artículo 3 del presente Acuerdo:

(a) Por "persona" se entenderá:

(i) Una persona física; y

(ii) cualquier persona jurídica, entidad u otro instrumento o forma jurídica, como por ejemplo una sociedad de capital, una sociedad de personas, un fideicomiso o una fundación.

(b) Por "trabajadores" se entenderá:

(i) En el caso de información a intercambiar por Gibraltar, los trabajadores por cuenta ajena o las personas físicas que desarrollen actividades empresariales o profesionales en Gibraltar y residan en España en municipios situados en un radio de $80 \mathrm{~km}$ desde Gibraltar.

(ii) En el caso de información a intercambiar por España, los trabajadores por cuenta ajena residentes en Gibraltar o las personas físicas que desarrollen actividades empresariales o profesionales en España en municipios situados en un radio de $80 \mathrm{~km}$ desde Gibraltar.

\section{Artículo 4. Órganos de enlace}

Las Partes designarán sus respectivos órganos de enlace competentes para llevar directamente a cabo las acciones de cooperación previstas en el presente Acuerdo. Cada Parte informará a la otra de los órganos de enlace designados en el plazo de un mes desde la entrada en vigor del presente Acuerdo. 


\section{Artículo 5. Comité Conjunto de Coordinación}

(1) Las Partes crearán un Comité Conjunto de Coordinación compuesto por las Autoridades designadas por las Partes, que supervisará y coordinará las actividades de cooperación previstas en el presente Acuerdo.

(2) Además, dicho Comité Conjunto de Coordinación se esforzará por resolver de mutuo acuerdo cualquier dificultad o duda que pueda surgir en relación con la interpretación o ejecución del presente Acuerdo, en particular en lo que se refiere al artículo 2, en aquellos casos concretos en que todas las autoridades que componen el Comité así lo decidan.

\section{Artículo 6. Intercambio de información, confidencialidad y protección de datos}

La información intercambiada en virtud del presente Acuerdo está sujeta a las normas previstas en los artículos 21 y 22 del Convenio sobre Asistencia Administrativa Mutua en Materia Fiscal de la OCDE y el Consejo de Europa.

\section{Artículo 7. Duración y terminación}

El presente Acuerdo permanecerá en vigor hasta que alguna de las Partes lo denuncie. Cualquier Parte podrá denunciar el Acuerdo, por vía diplomática, mediante una notificación al efecto remitida con al menos seis meses de antelación sobre el final del año natural. En dicho caso, el Acuerdo dejará de surtir efectos en relación con los tributos exigibles en cualquier ejercicio fiscal que comience desde el 1 de enero del año natural siguiente a aquel en que se hubiera remitido la notificación.

\section{Artículo 8. Entrada en vigor}

(1) El presente Acuerdo entrará en vigor en la fecha de la última de las notificaciones de las Partes indicando que han completado sus procedimientos internos, y surtirá efectos, en relación con lo dispuesto en los apartados (1) y (2) del artículo 2, para:

a) los periodos impositivos que comiencen desde la fecha de entrada en vigor del presente Acuerdo; o bien

b) cuando no haya periodos impositivos, respecto de las obligaciones fiscales devengadas desde la fecha de entrada en vigor del presente Acuerdo. 
(2) Las disposiciones del artículo 3 surtirán efectos a partir de la fecha de entrada en vigor del presente Acuerdo del siguiente modo:

(a) para los periodos impositivos iniciados desde el 1 de enero de 2014, respecto del intercambio automático de información previsto en las letras (a) y (b) del apartado (5) y en las letras (a) y (b) del apartado (10) de dicho artículo; y

(b) por lo que respecta a cualquier otro intercambio de información no previsto en la anterior letra (a), para los periodos impositivos iniciados desde el 1 de enero de 2011, o bien, cuando no haya periodos impositivos, respecto de las obligaciones fiscales devengadas desde el 1 de enero de 2011.

(3) Las demás disposiciones del presente Acuerdo surtirán efectos a partir de la fecha de entrada en vigor.

\section{Artículo 9. Extensión territorial}

En lo que respecta al Reino Unido, el presente Acuerdo se aplicará únicamente al territorio de Gibraltar.

HECHO en Madrid, el 4 de marzo de 2019, y en Londres, el 4 de marzo de 2019 , en dos ejemplares redactados en inglés y español, siendo ambos textos igualmente auténticos.

Por el Reino de España

Por el Reino Unido

\section{Josep Borrell Fontelles}

Ministro de Asuntos Exteriores, Unión Europea

y Cooperación 



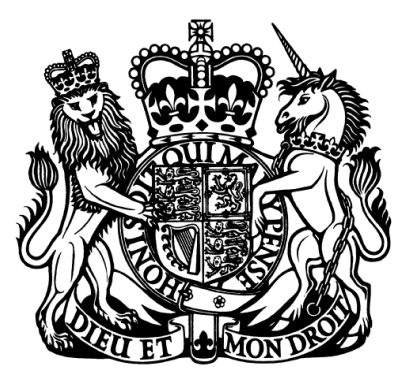

Spain No. 1 (2019)

\title{
International Agreement
}

on Taxation and the Protection of Financial Interests Between the United Kingdom of Great Britain and Northern Ireland and the Kingdom of Spain regarding Gibraltar

\author{
London and Madrid, 4 March 2019
}

[The Agreement is not in force]

Presented to Parliament

by the Secretary of State for Foreign and Commonwealth Affairs

by Command of Her Majesty

March 2019

CP 72 


\section{INTERNATIONAL AGREEMENT ON TAXATION AND THE PROTECTION OF FINANCIAL INTERESTS BETWEEN THE UNITED KINGDOM OF GREAT BRITAIN AND NORTHERN IRELAND THE KINGDOM OF SPAIN REGARDING GIBRALTAR}

CONSIDERING that, for the purposes of this Agreement, the United Kingdom acts as the State responsible for Gibraltar's external relations,

NOTING that the present Agreement, or any activity or measure taken in application or as a result thereof, do not imply any modification of the respective legal positions of the Kingdom of Spain or of the United Kingdom with regard to sovereignty and jurisdiction in relation to Gibraltar,

The parties, determined to improve co-operation in the field of taxation, and the protection of financial interests have agreed on the following:

\section{ARTICLE 1}

\section{Protection of Financial Interests and Tax Good Governance.}

(1) All the legislation and standards of the European Union as regards transparency, administrative cooperation, harmful tax practices and anti-money laundering shall continue to be applied in Gibraltar until the date on which EU law ceases to apply in Gibraltar.

(2) From the date on which EU law ceases to apply in Gibraltar, legislation equivalent to EU legislation which exists on that date shall be maintained in Gibraltar.

\section{ARTICLE 2}

\section{Tax Residency of Natural and Legal Persons, Entities and Other Legal Structures or Arrangements.}

\section{Natural Persons}

(1) For the purposes of this Agreement, the Parties agree that:

(a) Natural persons shall be tax resident in Spain or in Gibraltar in accordance with their domestic law, including rules regarding the issuance of tax certificates confirming residency and subject to the following rules only in cases of tax residency conflicts;

(b) Where by reason of the provisions in paragraph (1)(a) natural persons are resident of both Parties then their status shall be determined as follows: 
(i) Natural persons shall be tax resident only in Spain when any of the following circumstances exist:

A. They spend over 183 overnight stays of the calendar year in Spain. In determining the count of overnight stays, sporadic absences in neither Spain nor Gibraltar shall be added to the time where these individuals spend the majority of their overnight stays;

B. In the event that, pursuant to the Spanish tax legislation, their spouse (from whom they are not legally separated) or the natural person with whom a similar relationship has been established, and/or any dependent ascendants or descendants, resides or reside habitually in Spain;

C. The only permanent home at their disposal is in Spain; or

D. Two thirds of their net assets, determined pursuant to Spanish Tax legislation, whether held directly or indirectly, are located in Spain;

(ii) When the provisions of paragraph (1)(b)(i) are not conclusive, natural persons shall be considered tax residents only in Spain, unless they are able to provide reliable evidence that they have a permanent home for their exclusive use in Gibraltar and remain in Gibraltar over 183 days;

(iii) The Joint Coordination Committee provided for in Article 5 of this Agreement shall endeavour to resolve by mutual agreement any difficulties or doubts arising as to the interpretation or application of this paragraph (1)(b), where all the authorities forming the committee so decide;

(c) The following special rules for determining residency shall be applied in all cases without prejudice to the criteria set forth in the preceding paragraphs:

(i) Spanish nationals who move their residency to Gibraltar after the date on which this Agreement is signed shall in all cases only be considered tax residents of Spain;

(ii) Non-Spanish nationals who provide proof of their new residency in Gibraltar shall not lose tax residency in Spain. This rule shall apply in the tax period in which the change of residency is made and during the four subsequent tax years. This paragraph shall not apply to non-Spanish nationals that spend less than one complete tax year in Spain or registered Gibraltarians that spend less than 4 years in Spain; 
(d) For the purposes of paragraph (1)(c)(ii) above, registered Gibraltarians means any natural person as defined by section 4 of the Gibraltarian Status Act, generally British citizens that have resided in Gibraltar for over ten years;

(e) Gibraltar's special tax residency schemes for High Net Worth Individuals (HNWI), Category 2 Individuals (Cat 2), High Executive Possessing Specialist Skills (HEPSS) or any other equivalent scheme that may be created in the future, shall not of itself, constitute proof of tax residency in Gibraltar for the purposes of this Agreement.

\section{Legal Persons, Entities and Other Legal Structures or Arrangements}

(2) The following rules for determining tax residency apply:

(a) Legal persons, entities and other legal structures or arrangements, established and managed in Gibraltar, or governed by its legislation, shall be considered to have residency only in Spain when any of the following circumstances exist:

(i) The majority of the assets, whether directly or indirectly owned, are located in Spain or consist of rights that may or must be exercised in Spain;

(ii) The majority of the income accrued in a calendar year derives from sources in Spain, pursuant to article 13 of the codifying legislation of the Non-resident Income Tax Act of the Spanish tax legislation as may be amended from time to time;

(iii) The majority of the natural persons in charge of effective management are tax resident in Spain;

(iv) The majority of the interests in the capital or equity, voting or profit-sharing rights are under the direct or indirect control of either natural persons who are tax residents in Spain or legal persons, entities and other legal structures or arrangements linked to tax residents in Spain;

(b) Paragraphs (iii) and (iv) of paragraph (2)(a) above shall not apply to any legal person, entity and other legal structure or arrangement that is incorporated in Gibraltar before 16 November 2018, and that at 31 December 2018 when conditions in paragraph (2)(a)(iii) or (2)(a)(iv) are met, satisfies all of the following:

(i) has a fixed place of business through which the business is wholly or partly carried on in Gibraltar with an adequate number of 
employees, with the necessary qualifications and an adequate amount of operating expenditure with regards the core income generating activities;

(ii) is effectively subject to and pays Corporation Tax in Gibraltar on its profits at the prevailing rate in accordance with Gibraltarian tax legislation (presently $10 \%$ or $20 \%$ );

(iii) has for the period between the date of its incorporation and the 31 December 2018, operated in or from Gibraltar and has done so without interruption or a change in its trade since 1st January 2011;

(iv) has more than $75 \%$ of its income in respect of the financial year immediately preceding the 31 December 2018 , accruing in and deriving from sources in Gibraltar in accordance with Gibraltarian tax legislation as may be amended from time to time; and

(v) has less than the following incomes in respect of the financial year immediately preceding the 31 December 2018 from sources in Spain in accordance with Article 13 of the codifying legislation of the Non-resident Income Tax Act of the Spanish tax legislation as may be amended from time to time:

A. $5 \%$ for a legal person, entity and other legal structure or arrangement whose annual turnover exceeds 6 million euros;

B. $10 \%$ for a legal person, entity and other legal structure or arrangement whose annual turnover exceeds 3 million euros but does not exceed 6 million euros;

C. $15 \%$ for a legal person, entity and other legal structure or arrangement whose annual turnover does not exceed 3 million euros;

(c) When considering annual turnover in paragraph (2)(b)(v), turnover shall be taken to include that of the legal person, entity, other legal structure, or arrangement, together with the turnover of any related party incorporated in Gibraltar, where related party is defined in accordance with International Accounting Standard (IAS) 24 on Related Party Disclosures;

(d) In applying paragraph (2)(b), the Gibraltarian tax authorities, designated pursuant to Article 4 of this Agreement, shall provide the Spanish tax authorities with the list of the legal persons, entities and other legal structures or arrangements which meet the conditions of paragraphs (2)(a)(iii) or (2)(a)(iv) and also meet conditions in paragraphs (2)(b)(i) to (2)(b)(v) above at 31 December 2018. This list shall include details on 
the legal and beneficial ownership and the natural persons in charge of effective management of those legal persons, entities and other legal structures or arrangements and shall be provided by the Gibraltarian tax authorities by 31 March 2020;

(e) Spanish legal persons, entities, other legal structures or arrangements whose residency is moved to Gibraltar after the date of entry into force of this Agreement shall in all cases maintain tax residency only in Spain.

\section{Elimination of Double Taxation}

(3) The competent authorities shall eliminate, where relevant, double taxation pursuant to the provisions of their domestic law.

\section{ARTICLE 3}

\section{Administrative Cooperation in Tax Matters}

(1) The Parties shall apply an enhanced administrative cooperation with each other with a view to exchanging information that is foreseeably relevant to the administration, enforcement and collection concerning taxes of all kind and description imposed on behalf of the Parties, their territorial or administrative subdivisions, including local entities.

(2) From the date on which EU law ceases to apply in Gibraltar, the Parties shall apply with regard to each other measures that have equivalent effect to the principles and all of the modalities of Union legislation regarding mutual administrative assistance in force at any given time in the European Union. In particular the information and mechanisms provided by the Council Directive 2011/16 EU of 15 February 2011 on Administrative Cooperation in the field of taxation and repealing Directive 77/799 EC and its subsequent amendments (Directive 2014/107/EU of 9 December 2014, Directive 2015/2376/EU of 8 December 2015, Directive 2016/881/EU of 25 May 2016 and Directive 2018/822/EU of 25 May 2018), Directive 2010/24/EU of 16 March 2010 concerning mutual assistance for the recovery of claims relating to taxes, duties and other measures. Furthermore, the mechanisms set forth in the broadest terms in the OECD and Council of Europe's Multilateral Convention on Mutual Administrative Assistance in Tax Matters shall be applied, as too shall any OECD and G20 standards introduced in this sphere in the future.

(3) The liaison bodies designated pursuant to Article 4 shall provide mutual administrative assistance to each other in tax matters under this Agreement, whether the person affected is a resident or a non-resident of either Party. The following forms of co-operation shall be available in all cases: 
(a) The exchange of information, whether automatic, spontaneous or upon request, including simultaneous tax examinations or joint controls and participation in tax examinations abroad;

(b) Assistance with collection, including measures of conservancy, in accordance with their respective domestic laws; and

(c) The serving or transfer of documents.

(4) The liaison bodies further agree to automatically exchange information on the categories of information specified in paragraphs (5)(a) to (5)(b) and (10)(a) to (10)(b).

(5) The Gibraltarian tax authorities, designated pursuant to Article 4 of this Agreement, shall provide the Spanish tax authorities similarly designated, with the following:

(a) Annual information on workers registered in Gibraltar as residents in Spain, fully identifying every aspect of the underlying employment relationship or any trade, business, profession or vocation carried on or exercised by these workers, including details of duration, economic terms and employer;

(b) Six-monthly information on vessels, aircraft and motor vehicles registered in Gibraltar relating to tax residents in Spain;

(c) The direct and free access to the records of the Registrar of Companies in Gibraltar, provided for in the Directive on the prevention of the use of the financial system for the purposes of money laundering or terrorist financing, which amended Directives 2009/138/EC and 2013/36/EU, as well as to the Gibraltar Land Registry;

(d) Direct access to beneficial ownership information as is public or, on request to the Commissioner of Income Tax in Gibraltar on companies, any body corporate, partnerships and foundations;

(e) Direct access to information as is public or otherwise available to the Commissioner of Income Tax in Gibraltar on the settlors, trustees, beneficiaries, assets of all types of trusts, as well as to other legal structures or arrangements established or managed in Gibraltar, or governed by its legislation, when the settlors, trustees, protectors, beneficiaries, are tax resident in Spain or the assets held by all types of trusts are located in Spain.

(6) For the purposes of paragraph (5)(a) above, information is to be exchanged within four months after the end of the calendar year in which the taxable period ends. 
(7) The first exchange of information in respect of paragraph (5)(a) above, shall be in respect of taxable periods commencing on or after 1 January 2014 until the date of entry into force of this Agreement and shall be exchanged within four months of the date of entry into force of this Agreement.

(8) For the purposes of paragraph (5)(b) above, information is to be exchanged every six months, on 31 March and 30 September commencing on or after the date of the first exchange under this Agreement. The information exchanged on 31 March shall relate to the period 1 July to 31 December of the previous calendar year, and the information exchanged on 30 September shall relate to the period 1 January to 30 June of that same calendar year. The exchanges made shall ensure continuity of information provided such that no period is omitted between the first exchange of information after the date of entry into force of this Agreement and subsequent ongoing exchanges. These information exchanges shall only include details of new registrations of vessels, aircraft and motor vehicles.

(9) The first exchange of information in respect of paragraph (5)(b) above shall be in respect of taxable periods as they correspond to calendar years commencing on or after 1 January 2014 until the date of entry into force of this Agreement and shall be exchanged within four months of the date of entry into force of this Agreement. This information shall include the ownership, licence plate number, value and acquisition date regarding vessels, aircraft and motor vehicles registered in Gibraltar.

(10) The Spanish tax authorities, designated pursuant to Article 4 of this Agreement, shall provide the Gibraltarian tax authorities, similarly designated, with the following:

(a) Annual information on workers registered in Spain as resident in Gibraltar, fully identifying economic aspect of the underlying employment relationship or any trade, business, profession or vocation carried on or exercised by these workers, including details of duration, economic terms, annual and exempt income and employer;

(b) Six-monthly information on vessels, aircraft and motor vehicles newly registered in Spain relating to tax residents in Gibraltar.

(11) For the purposes of paragraph (10)(a) above, information is to be exchanged within four months after the end of the calendar year to which the information relates.

(12) The first exchange of information in respect of paragraph (10)(a) above, shall be in respect of taxable periods commencing on or after 1 January 2014 until the date of entry into force of this Agreement and shall be exchanged within four months of the date of entry into force of this Agreement.

(13) For the purposes of paragraph (10)(b) above, information is to be exchanged every six months, on 31 March and 30 September. The information exchanged on 31 March shall relate to the period 1 July to 31 December of the previous calendar year, and the information exchanged on 30 September shall relate to the period 1 
January to 30 June of the same calendar year. The exchanges made shall ensure continuity of information provided such that no period is omitted between the first exchange of information after the date of entry into force of this Agreement and subsequent ongoing exchanges. These information exchanges shall only include details of new registrations of vessels, aircraft and motor vehicles.

(14) The first exchange of information in respect of paragraph (10)(b) above shall be in respect of taxable periods as they correspond to calendar years commencing on or after 1 January 2014 until the date of entry into force of this Agreement and shall be exchanged within four months of the date of entry into force of this Agreement. This information shall include the ownership, license plate number, value and acquisition date regarding vessels, aircraft and motor vehicles registered in Gibraltar.

(15) For the purposes of Article 3 of this Agreement:

(a) 'Person' means:

(i) A natural person; and

(ii) A legal person, entity and other legal structure or arrangement such as a corporation, partnership, trust or foundation;

(b) 'Workers' means:

(i) In the case of the information to be exchanged by Gibraltar, natural persons that are employed and/or carry on a trade, business, profession, or vocation in Gibraltar and reside in Spain in municipalities situated within a radius of $80 \mathrm{~km}$ from Gibraltar;

(ii) In the case of information to be exchanged by Spain, natural persons resident in Gibraltar that are employed and/or carry on a trade, business, profession, or vocation in Spain in municipalities situated within a radius of $80 \mathrm{~km}$ from Gibraltar.

\section{ARTICLE 4}

\section{Liaison Bodies}

The Parties shall respectively designate the liaison bodies with competence to directly undertake the cooperation actions set forth in this Agreement. Each Party shall inform each other of the liaison bodies designated, within one month of the entry into force of this Agreement. 


\section{Joint Coordination Committee}

(1) The Parties shall create a Joint Coordination Committee formed by the Authorities designated by the Parties, which shall supervise and coordinate the cooperation activities set out in this Agreement.

(2) Additionally, the aforementioned Joint Coordination Committee shall endeavour to resolve by mutual agreement, any difficulties or doubts arising as to the interpretation or application of this Agreement, in particular regarding Article 2, in those specific cases where all the authorities forming the Joint Coordination Committee so decide.

\section{ARTICLE 6}

\section{Information Exchange, Confidentiality and Data Safeguards}

Information exchanged under this Agreement is subject to the rules provided in Articles 21 and 22 of the Convention on Mutual Administrative Assistance in Tax Matters of the OECD and the Council of Europe.

\section{ARTICLE 7}

\section{Duration and Termination}

This Agreement shall remain in force until terminated by a Party. Either Party may terminate the Agreement, through diplomatic channels, by giving notice of termination at least six months before the end of any calendar year. In such an event, the Agreement shall cease to have effect in respect of taxes chargeable for any tax year commencing on or after 1 January in the calendar year next following the year in which the notice is given.

\section{ARTICLE 8}

\section{Entry Into Force}

(1) This Agreement shall enter into force on the date of the later of the Parties' notifications that they have completed their internal procedures, and shall have effect for the provisions of paragraphs (1) and (2) of Article 2 for:

(a) taxable periods commencing on or after the date of entry into force of this Agreement; or 
(b) in cases where there are no such taxable periods, all charges arising on or after the date of entry into force of this Agreement.

(2) The provisions of Article 3 shall have effect after the date of entry into force of this Agreement as follows:

(a) for taxable periods commencing on or after 1 January 2014 in respect of the automatic exchange of information under paragraphs (5)(a) to (5)(b) and (10)(a) to (10)(b) of that Article; and

(b)in respect of any other exchange of information not addressed in paragraph (2)(a) above, for taxable periods commencing on or after 1 January 2011 or where there is no taxable periods, for all charges to tax arising on or after 1 January 2011.

(3) The remainder of the provisions of this Agreement shall have effect from the date of entry into force.

\section{ARTICLE 9}

\section{Territorial Extent}

With respect to the United Kingdom, this Agreement applies only to the territory of Gibraltar.

DONE in duplicate in London on 4 March 2019 and Madrid on 4 March 2019 in the English and Spanish languages, both texts being equally authoritative.

\section{For the United Kingdom of Great Britain and Northern Ireland:}

DAVID LIDINGTON

\section{For the Kingdom of Spain:}

\section{JOSEP BORELL FONTELLES}




\section{MEMORANDO DE ENTENDIMIENTO SOBRE COOPERACIÓN POLICIAL Y ADUANERA}

CONSIDERANDO que, a los efectos del presente Memorando, el Reino Unido actúa en su condición de Estado responsable de las relaciones exteriores de Gibraltar,

HABIDA CUENTA de que ni el presente Memorando, ni ninguna acción o medida tomada en aplicación o como resultado del mismo, conllevará una modificación de las respectivas posiciones jurídicas del Reino de España y del Reino Unido respecto de la soberanía y jurisdicción de Gibraltar,

\section{Cooperación policial y aduanera: principios generales}

Las partes intensificarán la cooperación en materia policial y aduanera, reforzando, así, la lucha común contra la delincuencia internacional y su compromiso mutuo de garantizar la seguridad y prosperidad de sus comunidades tanto en Gibraltar como en la zona circundante, en particular, en el Campo de Gibraltar.

Las partes declaran su profundo compromiso de colaborar estrechamente para la correcta aplicación de la legislación penal y aduanera a los efectos de prevenir y luchar contra los delitos y las violaciones de la legislación aplicable en ambas materias en Gibraltar y la zona circundante. Dicha cooperación se inspirará en los principios y mecanismos de cooperación administrativa y policial consagrados en la legislación penal y aduanera vigente en la Unión Europea.

\section{Cooperación policial}

La cooperación policial comprenderá los delitos previstos en la legislación penal vigente en Gibraltar y en la zona circundante, con independencia de si dichos delitos son cometidos por organizaciones o grupos criminales, entre ellos, sin perjuicio de la generalidad de lo anterior, los delitos de terrorismo, de tráfico y trata de personas, de tráfico de armas, de ciberdelincuencia, de tráfico de estupefacientes y otras mercancías, contra el medioambiente (incluyendo, el tráfico de residuos peligrosos y la pesca ilegal), de corrupción, el blanqueo de capitales y el fraude.

En el caso de los delitos relacionados con la seguridad vial, la cooperación se basará en la transferencia de los datos de las personas físicas que supuestamente los hayan cometido, así como en el intercambio de los datos de 
los titulares de los carnés de conducir y, en su caso, de las pólizas de seguro de los vehículos.

La cooperación policial comprenderá el intercambio de información sobre investigaciones financieras y patrimoniales.

Las respectivas autoridades policiales podrán definir y llevar a cabo los procedimientos de trabajo y protocolos de actuación conjuntos que sean necesarios para facilitar la cooperación prevista en los párrafos anteriores.

\section{Cooperación aduanera}

En todos los casos, la cooperación aduanera comprenderá lo siguiente:

a) El intercambio de información, por iniciativa propia o a instancia de cualquiera de las partes, que se considere necesaria para aplicar adecuadamente la normativa aduanera, evitar el fraude aduanero y el contrabando y luchar contra estas prácticas. Este intercambio se extenderá, asimismo, a los movimientos de dinero en efectivo y al blanqueo de capitales asociado al fraude aduanero y al contrabando.

b) La coordinación de los controles aduaneros.

c) La colaboración en operaciones conjuntas relacionadas con la circulación de mercancías sujetas a control aduanero. Este tipo de colaboración podrá consistir, cuando así lo acuerden de consuno, en cualquiera de las formas especiales de colaboración que prevén las disposiciones sobre cooperación aduanera vigentes en la Unión Europea.

d) La cooperación entre servicios aduaneros para luchar contra el contrabando y el tráfico de estupefacientes.

Las autoridades aduaneras competentes podrán definir y llevar a cabo conjuntamente los procedimientos de trabajo y protocolos de actuación conjuntos que sean necesarios para facilitar la cooperación prevista en los párrafos anteriores, entre los que se encuentran, en particular, los mecanismos de cooperación que se establecen en el presente Memorando y las formas especiales de cooperación previstas en los párrafos que siguen a continuación.

\section{Cooperación e intercambio de información}

La cooperación y el intercambio de información sobre el terreno se llevarán a cabo a través de los servicios territoriales de la Policía Nacional, la Guardia Civil y la Aduana de España en el Campo de Gibraltar, por una parte, y de la Policía Real de Gibraltar, la Administración de Aduanas de Gibraltar y las autoridades migratorias competentes de Gibraltar, por otra. 
La cooperación y el intercambio de información entre los servicios centrales de España y del Reino Unido, y viceversa, seguirá desarrollándose a través del Ministerio del Interior y el Ministerio de Hacienda de España y del Ministerio del Interior y el Ministerio de Hacienda y Aduanas (HMRC) del Reino Unido.

Las actas, registros, información, atestados, comunicaciones, certificados, informes, copias certificadas y otros documentos facilitados a través de los mecanismos de intercambio de información que elaboren, de conformidad con el ordenamiento interno de cada país, funcionarios de la autoridad requerida y remitidos a la autoridad requirente, podrán utilizarse como prueba, con arreglo a la legislación de la autoridad requirente.

No podrá transferirse a terceros la información confidencial que se intercambie al amparo de las disposiciones del presente Memorando sin el consentimiento expreso de la autoridad que haya facilitado la información, salvo lo previsto en el párrafo anterior.

\section{Comisión de Coordinación Conjunta}

El objeto de la Comisión prevista en el artículo 5 del Protocolo será garantizar la máxima eficacia en el ámbito de la cooperación policial y aduanera, ponderando también el estudio de las posibilidades de reforzar dicha cooperación en el futuro. Se invitará a la Unión Europea a participar en las reuniones de esta Comisión de Coordinación. La Comisión informará periódicamente al Comité Especial previsto en el artículo 165 del Acuerdo de retirada.

Cada una de las partes nombrará al mismo número de miembros de la Comisión e informará a la otra parte de dichos nombramientos, así como de cualquier posible cambio que puedan experimentar.

Por parte de España, la Comisión estará formada por representantes de la Secretaría de Estado de Seguridad, de la Policía Nacional, de la Guardia Civil, de la Agencia Tributaria, del Ministerio de Asuntos Exteriores, Unión Europea y Cooperación y de la Delegación del Gobierno en Andalucía.

Por parte británica, la Comisión estará formada por representantes del Ministerio de Relaciones Exteriores y de la Commonwealth y de la Policia Real de Gibraltar, de la Administración de Aduanas de Gibraltar y de las autoridades migratorias competentes de Gibraltar.

La Comisión adoptará su reglamento interno y trabajará por decisión conjunta de las partes. Asimismo, contará con un Grupo de Trabajo en materia policial y 
otro en materia aduanera, que coordinarán la colaboración operacional sobre el terreno entre los cuerpos y fuerzas que participen en las operaciones.

La Comisión se reunirá periódicamente. El orden del día, con los asuntos a tratar en las referidas reuniones, se acordará conjuntamente por adelantado. Cuando así se justifique por razones de urgencia o gravedad de la cuestión a tratar y esta no pueda resolverse en los Grupos de Trabajo, la Comisión podrá celebrar reuniones ad hoc. Se levantará acta de todas las reuniones haciendo constar los asuntos tratados del orden del día y, en su caso, los acuerdos adoptados, de tal manera que pueda realizarse un seguimiento adecuado de los mismos.

La Comisión establecerá mecanismos de cooperación operacional adecuados para garantizar la buena comunicación y el intercambio de información y otros elementos que aseguren la coordinación directa entre la policía y los servicios aduaneros que participen en las operaciones.

Para garantizar la máxima eficacia en materia de cooperación policial y aduanera, el Comité podrá proponer unas directrices de actuación a las correspondientes fuerzas del orden, de manera que puedan aplicarlas en sus operaciones.

Ambas partes nombrarán a sendos funcionarios de enlace en materia de cooperación policial y aduanera que, en los periodos que transcurran entre las reuniones, se esforzarán por asegurar que el diálogo y la colaboración entre sus respectivos servicios son adecuados y fluidos.

El presente Memorando dejará de surtir efectos el 31 diciembre 2020, salvo que las partes acuerden otra cosa.

Hecho en Londres, el29 de noviembre de 2018, y en Madrid, el 29 de noviembre de 2018, en dos ejemplares redactados en inglés y español, siendo ambos textos igualmente auténticos.

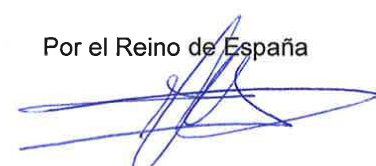

S. E. Josep Borrell Fontelles

Ministro de Asuntos Exteriores, Unión Europea y Cooperación
Por el Reino Unido

\section{S. E. David Lidington}

Ministro de la Presidencia y Canciller del Ducado de Lancaster (Minister for the Cabinet Office and Chancellor of the Duchy of Lancaster) 


\section{MEMORANDUM OF UNDERSTANDING ON COOPERATION IN POLICE AND CUSTOMS MATTERS}

CONSIDERING that, for the purposes of this Memorandum, the United Kingdom acts as the State responsible for Gibraltar's external relations,

NOTING that the present Memorandum, or any activity or measure taken in application or as a result thereof, do not imply any modification of the respective legal positions of the Kingdom of Spain or of the United Kingdom with regard to sovereignty and jurisdiction in relation to Gibraltar,

\section{Police and customs cooperation: General principles}

The Parties will intensify cooperation on law enforcement and customs matters, thus supporting the common fight against international crime and the mutual commitment to guarantee safe, secure and prosperous communities in both Gibraltar and the surrounding area, in particular the Campo de Gibraltar.

The Parties declare their deep commitment to close cooperation for the correct application of criminal and customs laws in order to prevent and combat criminal offences and infringements of the criminal and customs laws applicable in Gibraltar and in the surrounding area. Such cooperation will be inspired by principles and mechanisms of administrative and police cooperation set out in the criminal and customs laws in force in the European Union.

\section{Police cooperation}

Police cooperation will extend to the criminal offences provided for in the criminal legislation in force in Gibraltar and in the surrounding area, whether or not the criminal offences are committed by criminal organizations or groups, including, without prejudice to the generality of the foregoing, terrorism, people smuggling and trafficking, trafficking in weapons cybercrime, trafficking in drugs and other goods, environmental crimes (including illegal trafficking in hazardous waste, and illegal fishing), corruption, money laundering, and fraud.

In the case of criminal offences relating to road safety, cooperation will build on the transfer of data on individuals who are alleged to have committed such offences, as well as exchanging data on holders of driving licences and, as the case may be, of vehicle insurance policies.

Police cooperation will include exchanging information on financial and asset investigations. 
The respective police authorities may jointly develop and carry out any operational procedures and action protocols required to facilitate the cooperation set forth in the above paragraphs.

\section{Customs cooperation}

Customs cooperation will include in all cases:

a) Exchanging information, spontaneously or at the request of either Party, considered necessary for the proper application of customs regulations, and to prevent and combat customs fraud and smuggling. This exchange will extend to cash movements and to money laundering in relation to customs fraud and smuggling.

b) Coordination of customs controls.

c) Collaboration on joint operations relating to movement of goods subject to customs controls. This type of collaboration may include, when so jointly decided, any of the special forms of collaboration set forth in the provisions on customs cooperation in force in the European Union.

d) Cooperation between customs services to combat smuggling and drug trafficking.

The competent customs authorities may jointly develop and carry out any operational procedures and action protocols required to facilitate the cooperation set forth in the above paragraphs. These may include, in particular, the cooperation mechanisms set forth in the present Memorandum and the special forms of cooperation set forth in the following paragraphs.

\section{$\underline{\text { Cooperation and information exchange }}$}

Cooperation and exchange of information on the ground will be carried out through the territorial services in Campo de Gibraltar of Spain's National Police, Civil Guard, and Customs, on the one hand, and the Royal Gibraltar Police, HM Customs Gibraltar and the competent immigration authorities, on the other.

Cooperation and exchange of information between the United Kingdom and Spanish Central Services and vice versa will continue to be carried out through the United Kingdom's Home Office and Her Majesty's Revenue and Customs and Spain's Ministry of the Interior and Ministry of Hacienda.

Any minutes, records, information, proceedings, communications, certificates, reports, certified copies, and any other documents provided through the mechanisms for exchange of information, set up by or pursuant to their national law, by officials of the requested authority and transferred to the requesting 
authority, may be used as evidence, pursuant to the law of the requesting authority.

Confidential information exchanged under the provisions of the present Memorandum may not be transferred to third parties without the express consent of the authority providing the information, except as provided in the preceding paragraph.

\section{Joint Coordination Committee}

The purpose of the Committee referred to in article 5 of the Protocol will be to ensure the greatest effectiveness in police and customs cooperation including exploring options for strengthening that cooperation in future. The European Union will be invited to participate in the meetings of this Coordination Committee. The committee will report on a regular basis to the Specialised Committee of article 165 of the withdrawal agreement.

Each Party will have an equal number of members in the Committee and will inform each other of the members appointed and of any possible changes.

For Spain, the Committee will include representatives of the State Secretariat for Security; of the National Police; of the Civil Guard; of the Tax Agency; of the Ministry of Foreign Affairs, the European Union and Cooperation; and of the Government Delegation in Andalusia.

For the British side, the Committee will include representatives of the Foreign and Commonwealth Office, the Royal Gibraltar Police, HM Customs Gibraltar and the competent immigration authorities.

The Committee will adopt its rules of procedure and work by joint decision between the Parties. The Committee will also have a Working Group on Police, and a Working Group on Customs, which will coordinate operational collaboration on the ground between the respective participating forces and corps.

The Committee will hold periodic meetings. The agenda, together with the items of business for said meetings will be jointly decided in advance. When so required by the urgency or seriousness of the issue to be discussed, which cannot be resolved in the Working Groups, the Committee may hold ad hoc meetings. Minutes will be drawn up of each meeting, containing the agenda items discussed and, as the case may be, the decisions adopted, to enable the proper monitoring of the issues addressed or of the decisions adopted.

The Committee will establish the appropriate operational cooperation mechanisms to ensure good communication and transfer of information and any 
other elements guaranteeing direct coordination between police and customs services engaged in operational services.

To ensure the utmost effectiveness of police and customs cooperation, the Committee may propose action guidelines for the respective law enforcement services, so that they may be applied in the event of pursuits.

Each Party will appoint liaison officers for police and customs cooperation who, in the periods between meetings, will strive to guarantee appropriate and regular dialogue and collaboration between their respective services.

This Memorandum will cease to have effect on the $31^{\text {st }}$ December 2020 unless the Parties decide otherwise.

Signed in duplicate in London on 29November 2018 and Madrid on 29 November 2018 , in the English and Spanish languages, both texts having equal validity.

For the United Kingdom

The Rt Hon David Lidington

Minister for the Cabinet Office and Chancellor of the Duchy of Lancaster

\section{For the Kingdom of Spain}

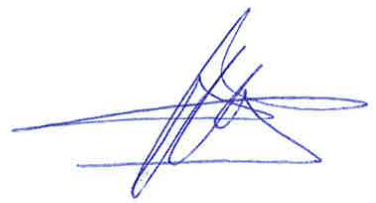

H.E. Josep Borrell Fontelles

Minister of Foreign Affairs, European Union and Cooperation 


\section{MEMORANDO DE ENTENDIMIENTO SOBRE LOS DERECHOS DE LOS CIUDADANOS}

CONSIDERANDO que, a los efectos del presente Memorando, el Reino Unido actúa en su condición de Estado responsable de las relaciones exteriores de Gibraltar,

HABIDA CUENTA de que ni el presente Memorando ni ninguna acción o medida tomada en aplicación o como resultado del mismo conllevará una modificación de las respectivas posiciones jurídicas del Reino de España y del Reino Unido respecto de la soberanía y jurisdicción de Gibraltar,

España y el Reino Unido convienen en crear una Comisión de Coordinación (en lo sucesivo, la "Comisión") de conformidad con el apartado 3 del artículo 1 del Protocolo de Gibraltar incluido en el Acuerdo relativo a la retirada del Reino Unido de Gran Bretaña e Irlanda del Norte de la Unión Europea y de la Comunidad Europea de la Energia Atómica (el "Acuerdo de retirada").

El objeto de la Comisión será garantizar la correcta aplicación de las disposiciones contenidas en el artículo 1 del Protocolo de Gibraltar, relativas a los derechos de los ciudadanos y los trabajadores. En este sentido, las autoridades laborales competentes garantizarán el cumplimiento de las mencionadas disposiciones. Todas las prestaciones sociales se extenderán a los trabajadores de ambas partes, en virtud de los acuerdos vigentes y de los que puedan suscribirse en el futuro, respetando plenamente el principio de no discriminación.

Cada parte nombrará a los miembros de la Comisión que habrán de representarla, de forma que ésta cuente con el mismo número de miembros de España y del Reino Unido. Cada una de ellas nombrará a un máximo de siete miembros e informará a la otra parte de dichos nombramientos, así como de cualquier cambio que pueda producirse en los mismos.

Por parte de España, la Comisión estará formada por:

- cuatro representantes de la Administración General del Estado, con competencia en los ámbitos estipulados en el artículo 1; la Comisión incluirá al menos a un representante del Ministerio de Asuntos Exteriores, Unión Europea y Cooperación;

- dos representantes de la Administración autonómica, propuestos por el Gobierno regional de Andalucía; 
- un representante de la Administración local.

Por parte del Reino Unido, la Comisión estará formada por:

- un representante nombrado por el Gobierno del Reino Unido;

- seis representantes nombrados por las autoridades gibraltareñas.

La Comisión se reunirá al menos una vez al trimestre; asimismo, podrá celebrar reuniones ad hoc a petición formal de cualquiera de las partes. Las reuniones de la Comisión se celebrarán alternativamente en el Campo de Gibraltar y en Gibraltar.

A los efectos de la organización administrativa y la gestión de las actividades de la Comisión, cada parte designará un punto de enlace; los dos se coordinarán por anticipado para preparar el orden del día de las reuniones de la Comisión. En su primera reunión, la Comisión aprobará, por acuerdo de sus miembros, los métodos de trabajo para desempeñar sus funciones. España y el Reino Unido facilitarán los procedimientos para el reconocimiento de los derechos y prestaciones de los trabajadores y los trabajadores transfronterizos. En particular, garantizarán la inscripción de los demandantes de empleo.

Si una de las partes de la Comisión considera que la otra parte está incumpliendo las obligaciones previstas en el artículo 1 del Protocolo de Gibraltar, la cuestión se someterá a la deliberación de la Comisión, que valorará la situación y formulará las oportunas recomendaciones. Si, transcurridos tres meses, una de las partes considera que no se ha abordado adecuadamente el incumplimiento, la cuestión se someterá al Comité establecido en virtud del artículo 165 del Acuerdo de retirada, cuyas funciones se determinan más pormenorizadamente en el artículo 6 del Protocolo de Gibraltar.

Hecho en Londres, el 29 de noviembre de 2018, y en Madrid, el 29 de noviembre de 2018, en dos ejemplares redactados en inglés y español, siendo ambos textos igualmente auténticos.

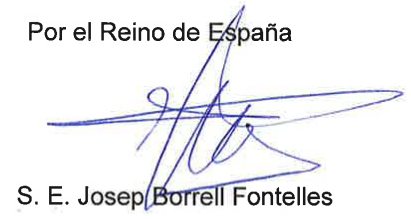

Ministro de Asuntos Exteriores, Unión Europea y Cooperación
Por el Reino Unido

\section{S. E. David Lidington}

Ministro de la Presidencia y Canciller del Ducado de Lancaster (Minister for the Cabinet Office and Chancellor of the Duchy of Lancaster) 


\section{MEMORANDUM OF UNDERSTANDING ON CITIZENS' RIGHTS}

CONSIDERING that, for the purposes of this Memorandum, the United Kingdom acts as the State responsible for Gibraltar's external relations,

NOTING that the present Memorandum, or any activity or measure taken in application or as a result thereof, do not imply any modification of the respective legal positions of the Kingdom of Spain or of the United Kingdom with regard to sovereignty and jurisdiction in relation to Gibraltar,

A Joint Coordinating Committee (hereinafter the "Committee") will be formed by the United Kingdom and Spain in accordance with Article 1(3) of the Protocol on Gibraltar included in the Agreement on the Withdrawal of the United Kingdom of Great Britain and Northern Ireland from the European Union and the European Atomic Energy Community (the "Withdrawal Agreement").

The purpose of the Committee will be to ensure that the provisions contained in article 1 of the Protocol on Gibraltar, concerning citizens' and workers' rights, are correctly applied. In this regard, the competent labour authorities will ensure compliance with the said provisions. All social benefits will be extended to workers on both sides, under current and future arrangements, in full respect of the principle of non-discrimination.

Each Party will appoint members of the Committee to represent them, in such a way that the Committee will have an equal number of members from Spain and from the United Kingdom. Each Party will appoint a maximum of seven members, and will inform the other Party of said appointments, as well as of any possible changes thereto.

On behalf of Spain, the Committee will include:

- Four representatives from the General State Administration, with competencies in the areas stipulated in article 1; the Committee will include at least one representative from the Ministry of Foreign Affairs, the European Union and Cooperation.

- Two representatives from the regional administration, proposed by the Regional Government of Andalusia.

- One representative from the local administration.

On behalf of the United Kingdom, the Committee will include: 
- One representative appointed by the United Kingdom Government.

- Six representatives appointed by the competent Gibraltarian authorities.

The Committee will meet at least quarterly; it may also hold ad hoc meetings at the formal request of either of the Parties. The Committee meetings will be held alternately in the District of Campo de Gibraltar and in Gibraltar.

For the purpose of administrative organization and management of the Committee's activities, each Party will appoint a focal point; the two focal points will coordinate in advance to prepare the agenda for Committee meetings. At its first meeting, the Committee will approve, by agreement between its members, the working methods for performing its functions.

The United Kingdom and Spain will facilitate the procedures for recognition of rights and benefits to workers and frontier workers. Particularly, registration of job seekers will be ensured.

If either of the Parties in the Committee considers that the other Party is not fulfilling all her obligations under article 1 of the Protocol on Gibraltar, the matter may be submitted for discussion by the Committee, which will assess the situation and may make recommendations. If, after three months have elapsed, one of the Parties considers that the failure has not been adequately addressed, the matter may be submitted to the Committee established by article 165 of the Withdrawal Agreement and whose role is further explained in article 6 of the Protocol on Gibraltar.

Signed in duplicate in London on 29November 2018 and Madrid on 29November 2018, in the English and Spanish languages, both texts having equal validity.

For the United Kingdom

The Rt Hon David Lidington

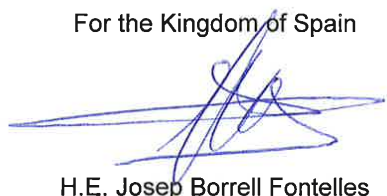

Minister for the Cabinet

Office and Chancellor of the

Duchy of Lancaster

H.E. Josep Borrell Fontelles

Minister of Foreign Affairs,

European Union and

Cooperation 


\section{MEMORANDO DE ENTENDIMIENTO SOBRE COOPERACIÓN EN MATERIA MEDIOAMBIENTAL}

CONSIDERANDO que, a los efectos del presente Memorando, el Reino Unido actúa en su condición de Estado responsable de las relaciones exteriores de Gibraltar,

HABIDA CUENTA de que ni el presente Memorando, ni ninguna acción o medida tomada en aplicación o como resultado del mismo, conllevará una modificación de las respectivas posiciones jurídicas del Reino de España y del Reino Unido respecto de la soberanía y jurisdicción de Gibraltar,

CONSCIENTES de la importancia de mantener rigurosas normas de protección del medioambiente, que contribuyan a un desarrollo económico y social sostenible y al mantenimiento de las buenas prácticas medioambientales tanto en Gibraltar como en la zona circundante, en particular, en el territorio de los municipios que conforman la Mancomunidad de Municipios del Campo de Gibraltar,

RECONOCIENDO que la cooperación entre las autoridades competentes es fundamental para garantizar la aplicación efectiva de los entendimientos estipulados en este Memorando de Entendimiento,

Las partes han convenido en lo siguiente:

A los efectos de lograr una cooperación reforzada en materia de protección medioambiental y de conformidad con el artículo 4 del Protocolo, se establecerá una Comisión Técnica y de Coordinación, que estará integrada por las autoridades competentes y empezará a ejercer sus funciones tan pronto como sea posible después del 30 de marzo de 2019. Las actividades de la Comisión Técnica y de Coordinación y de las autoridades competentes que la componen se llevarán a cabo sin perjuicio de las disposiciones del Derecho de la Unión Europea aplicable durante el período de transición.

Se invitará a la Unión Europea a participar en las reuniones de esta Comisión de Coordinación. La Comisión informará periódicamente al Comité Especial previsto en el artículo 165 del Acuerdo de retirada. 
Se nombrará un Presidente encargado de coordinar la Comisión Técnica y de Coordinación, cargo que rotará entre las autoridades competentes cada cinco meses. Las autoridades competentes desempeñarán sus funciones de buena fe y con el único interés de proteger y mejorar el medioambiente. En todas las reuniones de la Comisión Técnica y de Coordinación participarán representantes del gobierno central de España y del Reino Unido.

La Comisión Técnica y de Coordinación ofrecerá un foro para la cooperación reforzada y para el intercambio de información, previa solicitud, entre las autoridades competentes en materia de calidad del aire en Gibraltar y en la zona circundante, en particular, en el territorio de los municipios que conforman la Mancomunidad de Municipios del Campo de Gibraltar.

La Comisión Técnica y de Coordinación ofrecerá un foro para la cooperación reforzada y para el intercambio de información, previa solicitud, entre las autoridades competentes en materia de valoración del impacto medioambiental de los proyectos que se propongan tanto en Gibraltar como en la zona circundante, en particular, en el territorio de los municipios que conforman la Mancomunidad de Municipios del Campo de Gibraltar (incluida la recuperación de tierras) que puedan conllevar un importante impacto transfronterizo.

La Comisión Técnica y de Coordinación ofrecerá un foro para la cooperación reforzada entre las autoridades competentes en materia de calidad del agua y protección del hábitat marino tanto en Gibraltar como en la zona circundante, en particular, en el territorio de los municipios que conforman la Mancomunidad de Municipios del Campo de Gibraltar, así como para el intercambio de los datos científicos correspondientes. Con respecto a este último extremo, los buques de investigación científica con pabellón de la Unión Europea o del Reino Unido que pretendan llevar a cabo sus actividades en esta zona deberán informar a la Comisión Técnica y de Coordinación de su ruta, de la duración de su misión, de sus objetivos y de cualquier otra cuestión que la Comisión considere pertinente con antelación suficiente antes del inicio de las actividades. La Comisión tomará nota de la información proporcionada. La Comisión recibirá una copia de los resultados de las actividades de investigación. La Comisión fomentará el cumplimiento de los compromisos derivados del Derecho de la UE.

La Comisión Técnica y de Coordinación ofrecerá un foro para la cooperación reforzada entre las autoridades competentes en relación con el entorno marino en consonancia con el deseo de mantener rigurosas normas de protección medioambiental y fomentar un desarrollo sostenible tanto en Gibraltar como en la zona circundante, en particular, en el territorio de los municipios que conforman la Mancomunidad de Municipios del Campo de Gibraltar. La Comisión ofrecerá un foro para el debate en torno a las actividades pesqueras. 
La Comisión Técnica y de Coordinación, junto con el Grupo de Trabajo Aduanero contemplado en el Memorando de Entendimiento sobre cooperación policial y aduanera, ofrecerá, asimismo, un foro para la cooperación reforzada en materia de paso de residuos sólidos y escombros desde Gibraltar hacia España para su tratamiento en lugares distintos del vertedero de la Mancomunidad de Municipios del Campo de Gibraltar.

La Comisión Técnica y de Coordinación ofrecerá un foro para promover la más elevada protección medioambiental en lo que respecta a las actividades de repostaje.

El presente Memorando dejará de surtir efectos el 31 de diciembre de 2020, salvo que las partes acuerden otra cosa.

Hecho en Londres, el 29 de noviembre de 2018, y en Madrid, el 29 de noviembre de 2018, en dos ejemplares redactados en inglés y español, siendo ambos textos igualmente auténticos.

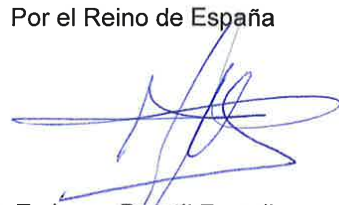

S. E. Josep Borrell Fontelles

Ministro de Asuntos Exteriores, Unión Europea y Cooperación
Por el Reino Unido

\section{S. E. David Lidington}

Ministro de la Presidencia y Canciller del Ducado de Lancaster (Minister for the Cabinet Office and Chancellor of the Duchy of Lancaster) 


\section{MEMORANDUM OF UNDERSTANDING ON COOPERATION ON ENVIRONMENTAL MATTERS}

CONSIDERING that, for the purposes of this Memorandum, the United Kingdom acts as the State responsible for Gibraltar's external relations,

NOTING that the present Memorandum, or any activity or measure taken in application or as a result thereof, do not imply any modification of the respective legal positions of the Kingdom of Spain or of the United Kingdom with regard to sovereignty and jurisdiction in relation to Gibraltar,

MINDFUL of the importance of maintaining high standards of environmental protection, that contribute to the sustainable economic and social development of and continuing good environmental practice in both Gibraltar and the surrounding area, in particular the territory of the municipalities that make up the Mancomunidad de Municipios del Campo de Gibraltar,

RECOGNISING that cooperation between the competent authorities is essential to ensure the effective implementation of the arrangements laid down in this Memorandum of Understanding,

The parties have reached the following understanding:

In order to deliver enhanced cooperation on environmental protection and in accordance with article 4 of the Protocol, a Technical and Coordination Committee ("the TCC") will be established, composed of the competent authorities, and will commence its functions as soon as practicable after 30 March 2019. The activities of the TCC and of the competent authorities in respect of the TCC will be without prejudice to the requirements of EU law applying during the transition period.

The European Union will be invited to participate in the meetings of this Coordination Committee. The committee will report on a regular basis to the Specialised Committee of article 165 of the withdrawal agreement.

A coordinating Chair of the TCC will be established and will rotate between the competent authorities every five months. The competent authorities will perform their functions hereunder in the utmost good faith and in the sole interest of the protection and the improvement of the environment. Representatives of the central governments of both Spain and the United Kingdom will participate in all meetings of the TCC. 
The TCC will provide a forum for enhanced cooperation, and for the exchange of information on request between the competent authorities, on air quality in both Gibraltar and the surrounding area, in particular the territory of the municipalities that make up the Mancomunidad de Municipios del Campo de Gibraltar.

The TCC will provide a forum for enhanced cooperation, and for the exchange of information on request between the competent authorities, on the assessment of the environmental impact of proposed projects in both Gibraltar and the surrounding area, in particular the territory of the municipalities that make up the Mancomunidad de Municipios del Campo de Gibraltar (including land reclamation) that are likely to have a significant transboundary effect.

The TCC will provide a forum for enhanced cooperation between the competent authorities in respect of water quality and the protection of the marine habitat in both Gibraltar and the surrounding area, in particular the territory of the municipalities that make up the Mancomunidad de Municipios del Campo de Gibraltar and for the sharing of related scientific data. As for the latter, scientific research vessels of EU or UK flag which intend to carry out their activities in that area will inform the TCC of their route, duration, objectives and any other matter the Committee will consider relevant with reasonable notice before the beginning of the activities. The TCC will note the information provided. The Committee will receive a copy of the findings of the research activities. The TCC will foster the fulfillment of the commitments derived from EU law.

The TCC will provide a forum for enhanced cooperation between the competent authorities in respect of the wider marine environment that is consistent with the desire to maintain high environmental standards and protection and facilitate sustainable development both in Gibraltar and in the surrounding area, in particular the territory of the municipalities that make up the Mancomunidad de Municipios del Campo de Gibraltar. The TCC will provide a forum for the discussion of fishing activities.

The TCC, alongside the Working Group on Customs referred to in the Memorandum of Understanding on Police and Customs Cooperation, will also provide a forum for enhanced cooperation in respect of solid waste and rubble crossing from Gibraltar to Spain for treatment in places other than the landfill of the Mancomunidad de Municipios del Campo de Gibraltar.

The TCC will provide a forum for promoting the highest environmental protection regarding bunkering activities. 
This Memorandum will cease to have effect on the $31^{\text {st }}$ December 2020 unless the Parties decide otherwise.

Signed in duplicate in London on29 November 2018 and Madrid on29November 2018 , in the English and Spanish languages, both texts having equal validity.

For the United Kingdom

The Rt Hon David Lidington

Minister for the Cabinet

Office and Chancellor of the

Duchy of Lancaster
For the Kingdom of Spain

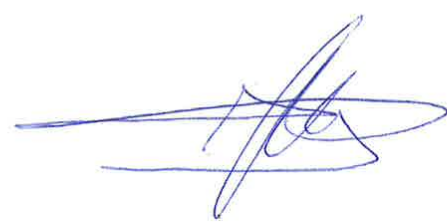

H.E. Josep Borrell Fontelles

Minister of Foreign Affairs, European Union and Cooperation 


\section{MEMORANDO DE ENTENDIMIENTO SOBRE EL TABACO Y OTROS PRODUCTOS}

CONSIDERANDO que, a los efectos del presente Memorando, el Reino Unido actúa en su condición de Estado responsable de las relaciones exteriores de Gibraltar,

HABIDA CUENTA de que ni el presente Memorando, ni ninguna acción o medida tomada en aplicación o como resultado del mismo, conllevará una modificación de las respectivas posiciones jurídicas del Reino de España y del Reino Unido respecto de la soberanía y jurisdicción de Gibraltar,

\section{DIFERENCIALES DE PRECIO}

1. Todas las partes interesadas han convenido en la necesidad de reducir el diferencial del precio de los productos del tabaco entre Gibraltar y la España peninsular y las Islas Baleares.

El gobierno de Gibraltar, preocupado por las consecuencias del tabaco para la salud y por la existencia de un comercio ilícito de tabaco en la zona circundante de Gibraltar que convive con el mercado legal de dicho producto, se ha comprometido a garantizar que, a fecha de 30 de junio de 2020 a más tardar, el diferencial del precio medio minorista de los productos de tabaco (cigarrillos, puros, picadura fina de tabaco y demás productos del tabaco) no superará el $32 \%$ del último precio español publicado para los mismos productos en la España peninsular y en las Islas Baleares. El compromiso sobre el diferencial del precio minorista no se aplicará a las ventas libres de impuestos de los productos del tabaco a pasajeros en puertos y aeropuertos. En lo que respecta a los cigarrillos, el mercado se dividirá en cuatro categorías de producto: los cigarrillos premium, los cigarrillos de precio medio-alto, los cigarrillos de precio medio-bajo, y los cigarrillos de precio más-bajo, con un precio mínimo fijado para cada categoría. En cuanto a la picadura fina de tabaco, el mercado se dividirá en dos categorías de producto: premium y no premium, con un precio mínimo fijado para cada categoría.

Las autoridades gibraltareñas competentes fijarán los precios mínimos minoristas de cada una de las categorías de productos del tabaco, que se publicarán trimestralmente en la Gaceta de Gibraltar, y se pondrán en marcha los mecanismos necesarios para garantizar que todos los minoristas respetan de forma efectiva los precios mínimos que establece la ley. 


\section{INTERCAMBIO DE INFORMACIÓN}

2. a) Sin perjuicio del respeto de las demás obligaciones a las que puedan estar sujetos, las partes establecerán mecanismos de seguimiento para intercambiar información relativa a las cantidades importadas, vendidas o exportadas de productos del tabaco. Dicha información comprenderá los datos relativos a cada uno de los siguientes extremos:

i. La cantidad de tabaco crudo o sin elaborar y de los productos del tabaco que hayan sido importados, vendidos o exportados hacia o desde Gibraltar.

ii. Con respecto al tabaco crudo o sin elaborar: datos de las importaciones, con especificación de la variedad, el origen, el exportador, el destino, el importador y el peso en kilogramos.

iii. Con respecto a los productos del tabaco, la información facilitada:

(1) Distinguirá entre los diferentes tipos de productos del tabaco: cigarrillos, tabaco de liar, tabaco de narguile, puros y puritos.

(2) Dicha información recogerá la tendencia de los precios minoristas de cada tipo de producto del tabaco e indicará: el precio medio ponderado de la cantidad vendida, el precio mínimo y el precio máximo.

(3) En relación con las ventas mayoristas o minoristas de cada tipo de tabaco, esta información distinguirá entre las ventas directas minoristas y las ventas libres de impuestos a los cruceros de placer $u$ otros medios de transporte.

3. Además, las partes compartirán información concreta relativa a la eficacia de los esfuerzos realizados para prevenir y luchar contra el fraude y el contrabando en la zona, incluida la legislación aprobada a estos efectos, las medidas administrativas y judiciales aplicadas, los recursos humanos y materiales empleados para luchar contra el fraude y el contrabando, y la cantidad y el valor de las incautaciones. Dicha información se extenderá también a la eficacia, en términos de lucha contra el comercio ilegal y el fraude, de la aplicación del contenido y las normas relativas a la trazabilidad.

4. La información contemplada en este subapartado tendrá carácter trimestral y se intercambiará en los primeros dos meses del trimestre siguiente al trimestre objeto de la información. 


\section{CUMPLIMIENTO}

5. A efectos de garantizar la efectividad de lo previsto en el apartado 3, el contenido de los principios y mecanismos regulados en las normas sobre asistencia mutua para la recaudación de ingresos de derecho público que puedan ser de aplicación en la Unión Europea para estos propósitos, las autoridades competentes cooperarán en la identificación de las personas domiciliadas en su respectivo territorio que, en el marco de procedimientos iniciados en relación con el contrabando de productos desde o hacia Gibraltar, puedan ser considerados directa o indirectamente responsables de dichos actos. Las autoridades competentes cooperarán también en esta zona en el marco de las investigaciones abiertas para la determinación de los hechos y la atribución de responsabilidad.

\section{Esta cooperación será recíproca e incluirá:}

a. La prestación de asistencia para el traslado, a todos sus destinatarios, de los documentos que indiquen las autoridades requirentes expedidos por la Administración requirente.

b. La entrega, a petición de la Administración requirente, de toda información individual relativa a elementos patrimoniales que sea pertinente a efectos de tributación, con el fin de recaudar las deudas debidas al Estado.

c. La recaudación, a petición de las autoridades requirentes, de las deudas debidas a la Administración, tal y como consten documentadas en un instrumento que facilite la ejecución y autorice las acciones de recaudación.

d. A petición de la Administración, y sobre la base del instrumento al que se refiere el punto anterior, la adopción de las medidas oportunas para garantizar la recaudación de las deudas debidas al Estado.

Las medidas antedichas podrán incluir cualesquiera de las siguientes:

a. La retención de cualquier pago que la Administración requerida deba hacer al supuesto deudor.

b. Medidas encaminadas a la congelación de elementos patrimoniales de un supuesto deudor.

c. Medidas u otros mecanismos que impidan la enajenación, el gravamen o el uso de elementos patrimoniales o el ejercicio de derechos con valor monetario.

d. Cualquier otra medida contemplada en la ley. 
7. Si existieran pruebas de que, como consecuencia de cualquiera de las medidas establecidas en el presente Memorando de Entendimiento, se estuviera introduciendo tabaco de contrabando en Gibraltar o en la zona circundante desde España en cantidades significativas, se adoptarán medidas efectivas para evitar esta actividad ilegal.

8. El Grupo de Trabajo Aduanero de la Comisión de Coordinación Conjunta en materia de cooperación policial y aduanera ofrecerá un foro de debate adecuado para todas las cuestiones dimanantes del presente Memorando de Entendimiento, en consonancia con su función de foro para el seguimiento y coordinación entre autoridades competentes de las cuestiones relacionadas con la cooperación en materia aduanera.

9. El presente Memorando dejará de surtir efectos el 31 de diciembre de 2020 , salvo que las partes acuerden otra cosa.

Hecho en Londres, el 29 de noviembre de 2018, y en Madrid, el 29 de noviembre de 2018 , en dos ejemplares redactados en inglés y español, siendo ambos textos igualmente auténticos.

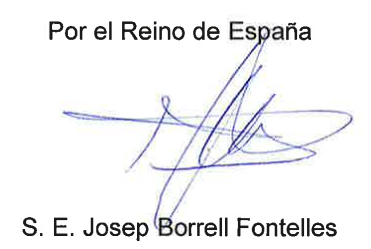

Ministro de Asuntos Exteriores, Unión Europea y Cooperación
Por el Reino Unido

\section{S. E. David Lidington}

Ministro de la Presidencia y Canciller del Ducado de Lancaster (Minister for the Cabinet Office and Chancellor of the Duchy of Lancaster) 


\section{MEMORANDUM OF UNDERSTANDING ON TOBACCO AND OTHER PRODUCTS}

CONSIDERING that, for the purposes of this Memorandum, the United Kingdom acts as the State responsible for Gibraltar's external relations,

NOTING that the present Memorandum, or any activity or measure taken in application or as a result thereof, do not imply any modification of the respective legal positions of the Kingdom of Spain or of the United Kingdom with regard to sovereignty and jurisdiction in relation to Gibraltar,

\section{PRICE DIFFERENTIALS}

1. All relevant Parties have decided on the need to reduce the price differential on tobacco products between Gibraltar and mainland Spain and the Balearics.

The Government of Gibraltar, being concerned about the health consequences of smoking and the existence of an illicit trade in tobacco in the area around Gibraltar, alongside the legitimate market in said commodity, has committed to ensure that, by 30th June 2020 the average retail price differential of tobacco products (cigarettes, cigars, fine cut tobacco, and other tobacco products) will be no more than $32 \%$ greater than the most recently published Spanish prices for the equivalent tobacco products in mainland Spain and the Balearics. The commitment on retail price differential will not apply to duty free sales of tobacco products to passengers in ports and airports. For cigarette products the market will be divided into four categories of product: premium cigarettes, mid-high cigarettes, mid-low cigarettes and lower-price cigarettes with a minimum price provided for each category. For fine cut tobacco, the market will be divided into two categories of product: premium and non-premium with a minimum price provided for each category.

The Gibraltarian competent authorities will set minimum retail prices for each of the categories of tobacco products, which will be published quarterly in the Gibraltar Gazette. The necessary mechanisms will be put in place to ensure effective compliance by all retailers with the minimum prices provided for in the law.

\section{INFORMATION SHARING}

2. Without prejudice to compliance with other obligations by which they may be bound, the Parties will establish monitoring mechanisms to exchange information concerning the amounts of tobacco products imported, sold or exported. This information will include details relating to each of the following:

i. The amount of raw or unmanufactured tobacco and tobacco products that have been imported, sold or exported from or to Gibraltar. 
ii. For raw or unmanufactured tobacco: details of imports, specifying variety, origin, exporter, destination, importer, and weight in kilos

iii. For tobacco products, the information provided will:

(1) Distinguish between the different types of tobacco products: cigarettes, rolling tobacco, hookah tobacco, cigars and miniature cigars.

(2) Said information will include the trend in retail prices for each tobacco product type, indicating: the weighted average price for the amount sold, minimum price and maximum price.

(3) As regards wholesale or retail, for each tobacco product type, said information will distinguish between direct retail sales and duty-free sales to leisure cruises or other forms of transport.

3. Additionally, the Parties will share specific information referring to the effectiveness of the efforts made to prevent and combat fraud and smuggling in the Area, including the legislation adopted for this purpose, the administrative and judicial measures applied, the human and material resources employed to combat fraud and smuggling, and the quantity and value of the seizures made. Said information will also extend to the effectiveness, in terms of combatting illicit trade and fraud, of applying the content and rules regarding traceability.

4. The information referred to in this subparagraph will be quarterly and will be exchanged within the first two months of the quarter following the quarter being reported.

\section{ENFORCEMENT}

5. To guarantee the effectiveness of the cooperation contained in paragraph 3 , the content of the principles and mechanisms provided in the rules on mutual assistance for collection of public-law revenues that may be applicable in the European Union for this purpose, the competent authorities will cooperate in identifying persons domiciled in their respective territories that, in proceedings undertaken in relation to smuggling of products originating from Gibraltar or destined for Gibraltar, may be found directly or indirectly responsible for said acts. The competent authorities will also cooperate in the Area in investigations to determine the facts and attribution of responsibility.

6. This cooperation will be reciprocal and will include:

a. Assistance in serving the documents indicated by the requesting authorities, issued by the requesting Administration, to all the addressees thereof.

b. Provision, at the request of the requesting Administration, of all individual information concerning assets that is relevant to taxation, for the purpose of collecting debts owed to the State. 
c. Collection, at the request of the requesting authorities, of debts owed to the Administration, as documented in an instrument that enables enforcement and authorises collection actions.

d. At the request of the Administration, based on the instrument stipulated in the preceding point, adoption of appropriate measures to ensure collection of the debts owed to the State.

Said appropriate measures may include any of the following:

a. Withholding any payments that the requested Administration are due to make to the alleged debtor.

b. Measures providing for the freezing of assets of an alleged debtor.

c. Measures or other mechanisms prohibiting disposal, encumbrance or use of assets or exercise of rights having a monetary value.

d. Any other measure provided for by law.

7. Should evidence emerge that as a result of any of the measures set out in this Memorandum of Understanding, tobacco is being smuggled into Gibraltar or the surrounding area from any part of Spain in significant quantities, effective action to prevent illicit activity will be taken.

8. The Working Group on Customs of the Joint Coordination Committee on police and customs cooperation will provide a forum for the discussion of all matters arising from this Memorandum of Understanding, in line with its function as a forum for monitoring and for coordination between the competent authorities of any questions related to cooperation in customs matters.

9. This Memorandum will cease to have effect on the $31^{\text {st }}$ December 2020 unless the Parties decide otherwise.

Signed in duplicate in London on 29 November 2018 and Madrid on 29 November 2018, in the English and Spanish languages, both texts having equal validity.

For the United Kingdom

The Rt Hon David Lidington

Minister for the Cabinet Office and Chancellor of the Duchy of Lancaster

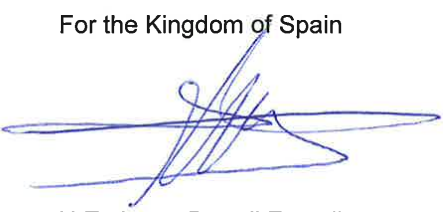

H.E. Josep Borrell Fontelles

Minister of Foreign Affairs, European Union and Cooperation 


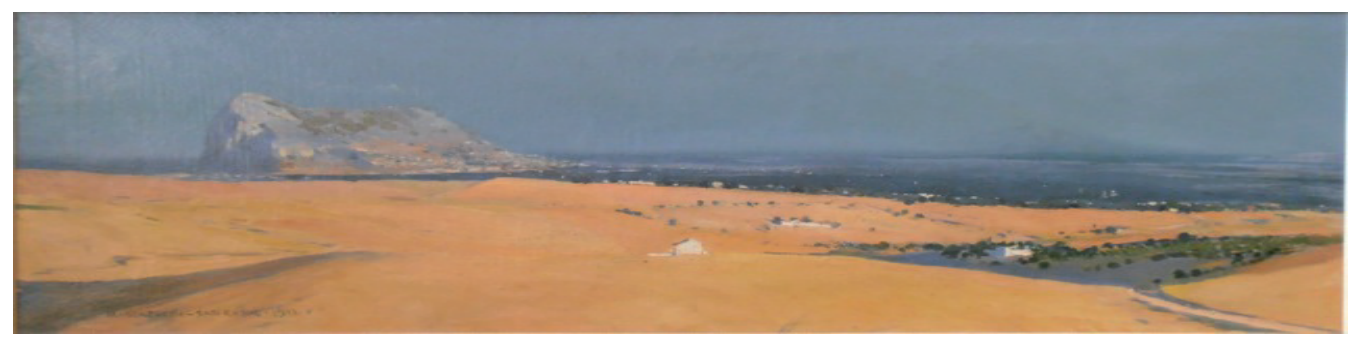

\section{Cuadernos de Gibraltar Gibraltar Reports}

\section{\#04 | 2020-2021}

Sumario

Table of Contents

\section{EDITORIAL}

Alejandro DEL VALLE GÁLVEZ; Inmaculada GONZÁLEZ GARCÍA, Gibraltar after the Brexit: Looking for a New and Imaginative Model of Cross-Border Cooperation in the EU Framework

\section{ESTUDIOS Y NOTAS}

Luis M. HINOJOSA MARTÍNEZ, Los movimientos de capital y los servicios financieros en las relaciones con Reino Unido y Gibraltar tras el Brexit: ¿Seguridad jurídica o ley de la selva?

Luis ROMERO BARTUMEUS, Las escalas de submarinos nucleares en Gibraltar y Rota, y los Planes de Emergencia Radiológica

Facundo D. RODRÍGUEZ, La cuestión de las Malvinas (Falklands) en el Cuarto Decenio Internacional para la Eliminación del Colonialismo

\section{ÁGORA}

Alejandro DEL VALLE GÁLVEZ, Creación de una AECT-Agrupación Europea de Cooperación Territorial- Campo de Gibraltar/Gibraltar (Guía breve sobre planteamiento, requisitos y procedimiento)

Alejandro GARCÍA HEREDIA, El Acuerdo Fiscal entre España y el Reino Unido en relación con Gibraltar

David CHEVASCO, Notes on Contemporary Bilingualism, Llanito and Language Policy in Gibraltar: a Study with a Present-day View of Linguistic Challenges

\section{DOCUMENTACIÓN}

Inmaculada GONZÁLEZ GARCÍA; Alejandro DEL VALLE GÁLVEZ; Lorena CALVO MARISCAL, Juan D. TORREJÓN RODRÍGUEZ:

Documentación I. Naciones Unidas - Gibraltar - Decisiones aprobadas por la Asamblea General de la ONU (2017-2019)

Documentación II. Brexit y Gibraltar - Tratado de Retirada, Protocolo, Tratado Fiscal y MOUs (2018-2020)

Documentación III. España, Brexit y Gibraltar. Declaraciones, Comunicados y Notas de Prensa (2018-2020)

Documentación IV. Andalucía, Brexit y Gibraltar (2018-2019)

Documentación V. Grupo Transfronterizo/Cross-Frontier Group, Memorándum de Entendimiento con el Gobierno de Gibraltar (2017) y Reglamento de Funcionamiento (2018)

Documentación VI. Principio de Acuerdo entre España y el Reino Unido sobre Gibraltar y sobre el Brexit, de 31.12.2020

Documentación VII. Mandato negociador para el Tratado entre el Reino Unido y la Unión Europea con respecto a Gibraltar, 5 de octubre de 2021

\section{LOS ARCHIVOS DE LUIS ROMERO BARTUMEUS}

La descolonización de Gibraltar, de CALVAR, J. - GUERITZ , E. J. - DEL CAMPO, S. - DAVIS H., Ed. Instituto de Cuestiones Internacionales, 1981, 110 páginas, por Luis ROMERO BARTUMEUS

Matar al Mensajero, Vivencias de un «Palomo» en Gibraltar, de TRIAY BOZZINO, J. J. - CASAUS BALAO, J. A., Ed. : Colecciones AUREA, 2000, 198 páginas, por Luis ROMERO BARTUMEUS

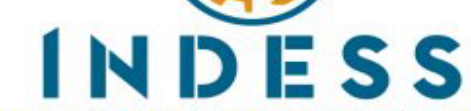

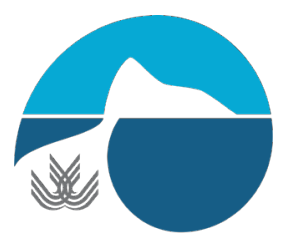

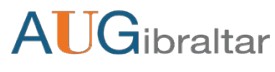

CÁTEDRA JEAN MONNET INMIGRACIÓN Y FRONTERAS DERECHO DE LA UNIÓN EUROPEA $\sim 2$

EDUCACIÓN DE LA UNIÓN EUROPEA

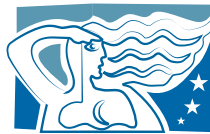

ESTUDIOS

INTERNACIONALES Y EUROPEOS

Centro de Estudios Internacionales y Europeos del Área del Estrecho 